\title{
Eyüb Sabri Paşa'nın Hayatı, Entelektüel Muhiti ve Eserleri Üzerine Bazı Yeni Bulgular
}

\section{New Remarks on the Life, Intellectual Climate, and Works of Eyüb Sabri Pasha}

\section{Ömer Faruk Can* (1)}

*Arș. Gör., Sakarya Üniversitesi, Fen Edebiyat Fakültesi, Tarih Bölümü, Sakarya, Türkiye

\section{ORCID: Ö.F.C. 0000-0002-3024-524X}

Sorumlu yazar/Corresponding author: Ömer Faruk Can,

Sakarya Üniversitesi, Fen Edebiyat Fakültesi, Tarih Bölümü, Sakarya, Türkiye

E-posta/E-mail: omerfarukcan@gmail.com

Başvuru/Submitted: 18.07 .2021

Kabul/Accepted: 13.09 .2021

\section{Atıf/Citation:}

Can, Omer Faruk. "Eyüb Sabri Paşa'nın Hayatı, Entelektüel Muhiti ve Eserleri Üzerine Bazı Yeni Bulgular." Tarih Dergisi - Turkish Journal of History, 75 (2021): 159-189.

https://doi.org/10.26650/iutd.973070

\section{ÖZ}

Bu çalışma, 19. yüzyıl Osmanlı'sının önde gelen münevverlerinden Eyüb Sabri Paşa ve eserlerini konu edinmektedir. Makalede Paşa'nın mevcut biyografisi detaylandırılmış ve içinde yer aldığı entelektüel muhit tespit edilmeye çalışıımıştır. Ayrıca Cuma hutbelerinin Türkçe okunması tartışmaları tarihine katkı sunabilecek bir yazısı ilk kez bu makalede mercek altına alınmıştır. Paşa'nın yaptırdığı Mescid-i Nebevî ve Mescid-i Haram maketlerinin akıbeti de sorgulanmış; böylece yeterince fark edilmeyen bir aydın devlet adamının hayatı ve eserleri derli toplu bir şekilde ortaya konarak Osmanlı entelektüel tarihiyle ilgili literatüre katkı sağlanması hedeflenmiştir.

Anahtar sözcükler: Eyüb Sabri Paşa, Mir'âtü'l-Haremeyn, Hicaz, Cuma hutbesi, Çocuk eğitimi, İttihad-ı İslâm

\section{ABSTRACT}

This study focuses on the life and works of Eyüb Sabri Pasha - an outstanding intellectual in the nineteenth-century Ottoman world - surveying the elegant cultural climate in which he lived as well as his distinguished entourage. The paper uncovers his article on delivering Friday sermons in Turkish, and investigates the fate of the Masjid an-Nabawi and Masjid al-Haram models. It contributes to the literature on the intellectual history of the Ottoman Empire by bringing to light the life and works of a nearly unnoticed intellectual and statesman.

Keywords: Eyüb Sabri Pasha, Mir'āt al-Haramain, Hijaz, Friday sermon (Khutbah), Child education, Pan-Islamism 


\section{Extended Abstract}

Eyüb Sabri Pasha (d. 1890), a Tanzimat intellectual and admiral, was also a prominent educator, Sufi, and historian. Despite his enlightened nature and substantial works of highquality and all-inclusive content, he has been understudied in the literature. This paper presents Eyüb Sabri's biography, using newly available documentation and data to contextualize his contribution to the Ottoman intellectual world. It also investigates the existing cultural climate, while studying this forgotten intellectual and statesman with a more comprehensive approach.

Little is known of Eyüb Sabri's family and childhood, except that he was enrolled in Mekteb-i Fünûn-ı Bahriye-i Şahane at the age of fifteen. His editorial dexterity was likely made clear at that point, as he was assigned clerking and teaching tasks. In 1872, the fortyyear-old Eyüb Sabri traveled to the Hejaz, and is believed to have served in the region for an extended period. However, considering other documentation and his responsibilities in Istanbul, it can be concluded that he spent roughly a year and a half on the Arabian Peninsula.

While serving as the head clerk, he taught literary composition (münşeat) at the Mekteb-i Bahriye and later, undertook the directorship of Kasımpaşa's Mekteb-i Rüşdiye-i Bahriye secondary school. During the initial years of his directorate, the school was not able to accomplish its mission, as the graduate turnout was lesser than expected.

He was a member of several commissions, starting with The Navy's Orphan Funds Investigation Commission (Bahriye Eytam Sandiklarl Tedkikat Komisyonu) and going on to The Naval Reform Commission (Islahat-ı Bahriye Komisyonu), that coordinated and carried out reforms and other naval initiatives.

During his career, he mainly worked on education, and spent considerable time on Haramain history and literature. At the age of fifty-eight, he had authored eight books totaling to thousands of pages as well as articles on a wide range of topics. His intellectual ability was drawn in part from his remarkable cultural entourage and partly due to his own investigative personality. The cultural climate was inhabited by prominent figures of the time, and thus, shaped his intellectual output and choices in the educational missions that he was devoted to. His responsibilities at the school and his works illustrate that he was passionate about nurturing that youth to be moral and well educated.

His literary works revolved around the life of Prophet Muhammad and the history and literature of the Hijaz. His magnum opus, Mir'âtü'l-Haremeyn, was mastered over the course of sixteen years that reflected in its quality, bringing the author recognition as one of the foremost historians of his period. He also contributed to newspapers with articles. The series of articles entitled Ayn-l Zübeyde explores the history and significance of Mecca's pivotal 
water supply. The Küçük Tercüman-ı Hakîkat for junior secondary school students released a series of his moral essays titled Nasîhatü'l-etfâl. In his essays, though the topics were largely embellished, they were written fluently and with tasteful style, peppered with numerous anecdotes and parables from Islamic history.

An essay published in Tercümân-ı Hakikat on the questions of reading the Friday sermon in Turkish, argued that part of the sermon should be translated into Turkish to foster adequate understanding. His suggestion encompassed reading the verses and hadiths alongside their Turkish interpretations and translating the advice expressed in the sermon into Turkish. This point, according to him, is the most crucial task for the goal of pan-Islamism.

Besides books and articles, he also modeled the Masjid al-Haram and Masjid al-Nabawi. In many ways, the models that he managed surpass their predecessors. First, the engineers' restoration plans were used during their construction to make them compatible with the authentic proportions of the mosques. The interior parts were given particular attention. The fate of these models is uncertain, but their traces have been followed based on three models located in Istanbul. Considering their size and the several sketches preserved in the Ottoman archives, the Masjid al-Nabawi model at Topkapi Palace might be his work.

To conclude, this study reveals Eyüb Sabri Pasha's prominent and diverse environment, including the influence of statesmen, poets, authors, sheikhs, and journalists from many segments of society. It shows that he shares the Tanzimat generation's concerns regarding education and writing. It also uncovers his essay on the question of the language of the Friday sermon, which is noteworthy for pioneering discussions regarding worshiping in Turkish. For the first time, this article surveys a series of papers on child education in the context of his life story. Finally, it analyzes the destiny of his Masjid al-Nabawi and Masjid al-Haram models, indicating that the former could be the model that is currently on exhibit at the Topkapi Palace. 


\section{Giriș}

Osmanlı son devrinde eskilerin sâhib-i yed-i tûlâ şeklinde tarif ettikleri, kendisini birçok sahada yetiştirmiş veya o sahada uzmanlaşmış kişilere rastlamak mümkündür. İlk akla gelenler arasında Ahmed Cevdet Paşa, Ahmed Midhat Efendi, İbnülemin Mahmud Kemal ve İsmail Saib gibi isimler bu meyanda zikredilebilir. Bu isimler kadar günümüzde popüler olmayan, tâbir câizse meşâhir-i meçhûleden kimi kişiler de hiç şüphesiz mevcuttur. Ortaya koyduğu eserlerden ilmî derinliğine, entelektüel birikimine vâkıf olabileceğimiz Eyüb Sabri Paşa (1832/33-1890) işte bu kategorideki isimler arasında değerlendirilebilir.

"Tersaneden yetişen" Eyüb Sabri, asker olmasının yanında eğitimci, mutasavvıf ve tarihçi yönleriyle öne çıkan bir Tanzimat münevveridir. Sultan Abdülmecid, Abdülaziz ve V. Murad devirleri ile en önemli eserlerini ortaya koyduğu II. Abdülhamid saltanatının on üç senesini idrak etmiş, askerlik silkinde de mirlivalık (tümgeneral) rütbesine kadar yükselmiştir. Aydın kişiliği ile eserlerinin nitelik ve kapsamca öneminin aksine, Paşa'nın şahsiyeti ve eserlerinin literatürde hak ettiği ilgiye ulaşamadığı söylenebilir. Tabakat kitapları, genelde eserlerine dair kısa bilgiler vermekle yetinmekte ${ }^{2}$, eserlerinde istitrad kabilinden birçok konuya temas etmeyi seven Paşa ise kendi hâl tercümesinden pek bahsetmemektedir. Çeşitli ansiklopedik neşirlerin de Paşa'nın hayatını -mahiyetleri gereği- belli sınırlılıklar içerisinde verdiği dikkati çekmektedir ${ }^{3}$.

Eyüb Sabri Paşa'nın hayat hikâyesinin kimi kısımları ile entelektüel yönü ve bazı eserleri bu makalenin odak noktasını oluşturmaktadır. Esasında onun hayatı ve eserlerine dair bir araştırma daha önce yapılmışs, tarihçiliğine odaklanan bir çalışma ise Mehmet Akif Fidan

1 Mehmed Süreyyâ, "Eyyûb Sabrî Paşa", Sicill-i Osmânî yâhûd Tezkire-i Meşâhîr-i Osmâniyye, I, Matbaa-i Âmire, İstanbul 1308/1890, s. 451.

2 Paşa hakkında bilgi veren ilk biyografik eser Sicill-i Osmânı̂ ve ardından Osmanlı Müellifleri' dir (Mehmed Süreyyâ, “a.g.m.”, s. 451; Bursalı Mehmed Tahir, “Eyüb Sabri Paşa”, Osmanlı Müellifleri, III, haz. M. A. Yekta Saraç, ed. Mustafa Çiçekler, TÜBA, Ankara 2016, s. 959).

3 Bu eserler şunlardır: İbrahim Alaettin, "Eyüp Sabri Paşa”, Meşhur Adamlar: Hayatları - Eserleri, II, nşr. Sedat Simavi İstanbul 1933-1935, s. 446; Ömer Rizâ Kehhâle, "Eyyûb Sabrî", Mu 'cemü'l-Mü'ellifin: Terâcimü Musannifi'l-Kütübi'l-Arabiyye, III, Beyrut 1957, s. 30; Bernard Lewis, "Ayyûb Sabrî Pasha", The Encyclopedia of Islam (EI), I, E. J. Brill - Luzac \& Co., Leiden-London 1960, s. 796; Reşad Ekrem Koçu, "Eyyub Sabri Paşa", İstanbul Ansiklopedisi, X, Koçu Yayınları, İstanbul 1971, s. 5446; Franz Babinger, Osmanlı Tarih Yazarları ve Eserleri, çev. Coşkun Üçok, Kültür ve Turizm Bakanlı̆̆ı, Ankara 1992, s. 404-405; Azmi Özcan, "Eyüp Sabri Paşa”, DİA, XII, İstanbul 1995, s. 8-9; Azmi Özcan, "Eyüp Sabri Paşa", Yaşamları ve Yapttlartyla Osmanlılar Ansiklopedisi, I, Yapı Kredi Yayınları, İstanbul 1999, s. 429; İhsan Işık, "Eyüb Sabri Paşa", Resimli ve Metin Örnekli Türkiye Edebiyatçılar ve Kültür Adamları Ansiklopedisi, IV, Elvan Yayınları, Ankara 2006, s. 1368. Bu maddelerin yanında Şaban Er bir çalışmasında Eyüb Sabri Paşa'nın kısa tercüme-i hâlini vermiş ve ilgili birtakım arşiv vesikasını günümüz harflerine aktarmıştır. Şaban Er, Melâmîlik ve Osmânlı Devri Melâmîleri (Hâl tercümeleri, Silsileleri, İtikâdlarl, Meşrebleri, Eserleri, Eserlerinden Seçmeler, Tipkibasımlar, Arşiv Vesikaları, Fotoğraflar), Kutupyıldızı Yayınları, İstanbul 2015, s. 580-607.

4 Ömer Faruk Can, "Giriş: Bir Münevver Bahriyeli: Eyüb Sabri Paşa", Mir' âtü' 'l-Haremeyn (Haremeyn Tarihi): Mir' 'ât-l Mekke (İnceleme-Metin), I, mlf. Eyüb Sabri Paşa, Türkiye Yazma Eserler Kurumu Başkanlığı, İstanbul 2018, s. 51-113 (Can, "Giriş"). 
tarafından doktora tezi olarak savunulup akabinde neşredilmiştir ${ }^{5}$. Bu makalede ise ailesi, eğitim hayatı ve görevleri hakkında edinilen yeni belge ve bilgilerle Paşa'nın biyografisi geliştirilmiş, ayrıca üstlendiği görevlerin mahiyeti ve kaleme aldığı yazıların muhtevası doğrultusunda döneminin entelektüel arenasındaki varlığı bir bağlama oturtulmaya çalışılmıştır. Bu minvalde, içinde bulunduğu kültürel muhite de temas etmeye çalışılarak, yeterince fark edilmeyen bir aydın devlet adamının portresinin daha anlamlı bir şekle bürünmesi amaçlanmıştır.

Deniz Tarihi Arşivi (DTA) ile Başkanlık Osmanlı Arşivi’ndeki (BOA) arşiv malzemelerinin yanı sıra salnâmeler, Paşa'nın eserleri ve gazetelerde yayınlanan yazıları, bu çalışmanın aslî kaynaklarını oluşturmaktadır. Bu kaynaklar arasında bulunan, Paşa'nın Cuma hutbesinin Türkçe okunması tartışmaları tarihine katkı sunabilecek bir makalesi ilk defa bu makalede mercek altına alınmıştır. Yine, çocuk eğitimine dair bir yazı dizisi, Paşa'nın hayat hikâyesi bağlamında ilk kez incelenmiştir. Nihayet, Paşa'nın kitap ve gazete yazıları haricindeki eserlerinden olan Mescid-i Nebevî ve Mescid-i Haram maketlerinin akıbetleri de etraflıca sorgulanmış, mevcut literatürdeki kimi tutarsız ve hatalı bilgiler tashih edilmiştir.

\section{1. Öğrenmeye ve Yazmaya Adanmış Bir Hayat}

Günümüzde Yunanistan'da bulunan Yenişehir (Larissa) civarındaki Ermiye'de (Almiros) dünyaya gelen (1248/1832-33) Eyüb Sabri’nin ${ }^{6}$, bir eserinde zikrettiği künyesinden hareketle, seyyid ve babasının paşa olduğu söylenebilir ${ }^{7}$. Ailesine dair pek bilgi bulunmamaktadır; elimizdeki kayıtlardan evli ve en azından bir kız babası olduğu anlaşılmaktadır ${ }^{8}$.

Kızı hakkında herhangi bir bilgimiz olmamasına karşın, yine kendisi gibi bahriyeli olan damadı hakkında biraz malumat sahibiyiz. Zira on altı senede kaleme aldı̆̆ı Mir'âtü'lHaremeyn'in basım masraflarından ötürü borçlu vefat eden Paşa'nın borçları, damadı İnşâiye Binbaşısı Arif Bey'in Bahriye Nezareti'ne bir arzuhâl yazmasıyla ancak tesviye edilebilmiştir. 1890-91 yıllarına ait Bahriye salnâmelerine göre Arif Bey'in 1282'de (186566) Bahriye'ye girdiğgi, 1300'den (1883) itibaren de İnşâiye Resimhanesi'nde görevli olduğu anlaşılmaktadır. Mekteb-i Bahriye'den mezun olan Arif Bey, bir gümüş madalya, bir sanayi madalyası ve Dördüncü Dereceden Mecîdî Nişanı'na lâyık görülmüştür? .

5 Mehmet Akif Fidan, Eyüp Sabri Paşa ve Tarihçiliği, Türk Tarih Kurumu Yayınları, Ankara 2011.

6 Sâlnâme-i Askerî: Sene 1283, Mekteb-i Harbiye-i Şâhâne, İstanbul 1283/1866, s. 393 'ten aktaran Fidan, a.g.e., s. 43.

7 Azîzü'l-âsâr adlı eserinde künyesini “Eyyûb es-Sabrî ibnü’s-Seyyid Şerîfü'l-İslâm ibnü'l-Hâc Ahmed elErmiyevî” olarak zikreder (Eyüb Sabri, Azîzü 'l-âsâr Şerh-i Kasîde-i Bânet Sü 'âd, Şeyh Yahyâ Efendi Matbaası, İstanbul 1291/1874, s. 282'den aktaran Fidan, a.g.e., s. 43). Nitekim Şaban Er de Melâmîlik ile ilgili kitabında Paşa'nın evlad-1 Resul'den olduğunu vurgular (Er, a.g.e., s. 580).

8 Fidan, a.g.e., s. 47-48.

9 Sâlnâme-i Bahrî: Sene 1307, Bahriye Nezâreti Fen Komisyonu, İstanbul 1307/1890, s. 102; Sâlnâme-i Bahrî: Sene 1308, Bahriye Nezâreti Fen Komisyonu, İstanbul 1307/1890, s. 86. 
Hayatının ilk dönemine dair bilgimizin bulunmadığ $1^{10}$ Eyüb Sabri, kuvvetle muhtemel memleketinde ilk tahsilini tamamladıktan sonra yüksek tahsil için İstanbul'a geldi. On beş yaşında bir delikanlı iken Mekteb-i Fünûn-1 Bahriye-i Şâhâne’ye girdi (8 Mart 1848) ${ }^{11}$. Kimi araştırmacılar, künye defterindeki 8 Mart 1848 tarihinin mektebe veya mesleğe girişten hangisini gösterdiği hususunda tereddüt gösterse de ${ }^{12}$ defterdeki "rızâsıyla duhûlü" ibaresi tereddütleri izâle etmeye kâfidir. Çünkü bu ifade, normalden daha erken yaşlarda mektebe girenlerin rızalarının alındığına işaret etmek üzere ve özellikle yüksek mektepler için kullanılmaktaydı ${ }^{13}$. O hâlde bunu, o dönemde on beş yaşındaki biri için rüşdiye veya idâdîden ziyade yüksek mektebe giriş tarihi olarak yorumlamak doğru olacaktır. Nitekim sekiz sene sonra Eyüb Sabri'nin mülâzım-1 evvelliğe (üsteğmen) getirilmesi, dört sene süren eğitiminin ardından ${ }^{14}$ dört yıl mülâzım-1 sânî (teğmen) olarak vazife aldığını gösterir ki bu, dönemin teâmüllerine uygundur ${ }^{15}$.

O dönemde Mekteb-i Bahriye'de coğrafya, fünûn-1 bahriye, matematik, usûl-i hendese, cebir ve teknik resim gibi dersler verilmekteydi ${ }^{16}$. Eyüb Sabri'nin mektebe kabul edildiği 1848 senesi ise mektep tarihinde yabancı dil eğitimi açısından bir dönüm noktasını teşkil etmektedir. O zamana dek Arapça, Farsça ve Rumcanın yanı sıra yabancı dil olarak Fransızca öğretilmekteyken ${ }^{17}$ Patrona-i Hümâyun (İngiliz) Mustafa Paşa'nın teklifi ile Fransızcanın seçmeli, İngilizceninse mecburî ders olması gündeme geldi ${ }^{18}$. İngiltere'nin deniz harp sanayii ve teknolojisindeki üstünlükleri malumdu ve denizcilik literatüründen istifade için bu dilin bilinmesi gerekmekteydi ${ }^{19}$.

10 Son dönem Osmanlı biyografi yazıcılığının temel problemlerine dair bkz. Ali Akyıldız, "İnsanı Yazmak: 19. Yüzyıl Osmanlı Biyografi Yazıcılığı ve Problemleri Üzerine Bir Değerlendirme”, Osmanlı Araştırmaları, sayı 50 (Ekim 2017), s. 219-242.

11 DTA, YKL.d, 3972/21, 25 Şubat 1263 (8 Mart 1848).

12 Mesela bkz. Fidan, a.g.e., s. 45-46.

13 Patrona-i Hümâyun Mustafa Paşa'nın Mekteb-i Bahriye'ye dair lâyihasını müteakip Nisan 1848'den itibaren yüksek mektep için yaş aralığı 14-16 olarak belirlenmiştir. Bkz. Safvet, Bahriyemiz Târîhinden Filasalar, Matbaa-i Bahriye, [İstanbul] 1329/1911, s. 15.

14 Patrona'nın lâyihasında eğitimin dört sınıfa taksim olunduğu ifade edilmektedir (Safvet, a.g.e., s. 14).

15 Can, “Giriş", s. 53-54. Eyüb Sabri Efendi'nin ne zaman mezun ve mülâzım-1 sânî olduğuna dair bir kayda rastlanmamıştır.

16 Ali İhsan Gencer, Bahriye 'de Yapılan Islahat Hareketleri ve Bahriye Nezareti'nin Kuruluşu (1789-1867), Türk Tarih Kurumu Yayınları, Ankara 2001, s. 271.

17 Gencer, a.g.e., s. 271.

18 Safvet, a.g.e., s. 13-18; Gencer, a.g.e., s. 274-277. İngiliz nüfuzu ilk olarak 1820'lerde buharlı gemi teknolojisinin gelişmesiyle Osmanlı bahriyesinde etkisini göstermeye başlamış ve sonraki yıllarda bu etki iyiden iyiye artmıştır (Levent Düzcü, "Osmanlı'nın Endüstri Devrimine İlk Adımları: Küçük ve Büyük Vapur", Kadim, sayı 2 (Ekim 2021), s. 115-116). Nitekim uzun y1llar İngiltere’de bulunan ve İngiliz kültüründen derinden etkilenen Said Paşa'nın Bahriye'de nazırlık, Mekteb-i Bahriye müdürlüğü ve Bahriye Meclisi üyeliği gibi mühim görevler deruhte etmesi bu döneme rastlar (Burhan Çağlar, "1878-1879 Zeytun Ermeni İsyanları ve İngiliz Said Paşa'nın Aldığı Tedbirler”, Ermeni Araştırmaları, sayı 46 (2013), s. 165-166; Daniel Panzac, Osmanlı Donanması (1572-1923), çev. Ahmet Maden - Sertaç Canpolat, Türkiye İş Bankası Kültür Yayınları, İstanbul 2018, s. 349-350).

19 Bu değişiklik sadrazam buyuruldusunda şöyle ifade edilmiştir: “... Ingilterelünün denizce derkâr olan mahâret-i müselleme ve kemâlleri münâsebetiyle onların bu fünûna dâ 'ir olan kitâblarının elbette rüchâniyyeti olacağından vâsıta-i ta lîm olmak üzere Ingiliz lisânının tahsîline mecbûriyyet olacağı cihetle...” (Safvet, a.g.e., s. 19). Osmanlı denizciliğinde İngilizcenin yükselişine Amerika'nın etkisi de eklenebilir (Kenan Sayacı, Deniz Harp Okulu Tarihçesi, Ankara 2000, s. 40). 
Eyüb Sabri, mektepte İngilizceyi iyi bir şekilde öğrenmiş olmalıdır. Nitekim Mir'âtü'lHaremeyn' de kaynak olarak birçok İngilizce eser kullandığı görülür. Ezcümle, İngiliz tarihçi Edward Gibbon (1737-1794), seyyah Johann Burckhardt (1784-1817) ve Mekke'yi ziyaret eden ilk İngiliz olarak gösterilen Ekseterli Joseph Pitts'in (1663-1735?) eserleri yanında İtalyan seyyah Ludovico di Varthema'nın (c. 1470-1517) “Ingiliz lisânına bi t-tercüme tab “ u neşr edilmiş" eserinden de yararlanmıştır ${ }^{20}$.

Mekteb-i Bahriye'den mezun olduktan sonra o dönemde gelenek olduğu üzere donanma gemilerinden birinde mülâzım-1 sânî olarak yaklaşık dört sene görev yapan Eyüb Sabri, yirmi üç yaşındayken mülâzım-1 evvelliğe yükseltildi (13 Ağustos 1855) ${ }^{21}$; beş sene boyunca bu rütbede hizmet etti. Bir sonraki görevi, Bahriye'nin ağır sanayiyi ilgilendiren çeşitli bölümlerinde görev alacak kalifiye elemanları yetiştirmek maksadıyla kurulan Bahriye Sanayi Alayları'nda idi $^{22}$; 27 Haziran 1860 tarihinde Bahriye Sanayi Alayı beşinci taburunun kâtibi oldu ${ }^{23}$. Daha sonra Bahriye'nin kitâbet cihetinde istihdam edilmeye devam etti; 13 Temmuz 1866'da alay kâtipliğine terfi ederek, Tersâne-i Âmire Şeşhâneci Alayı'nın kâtibi oldu ${ }^{24}$. Tabur ve alay kâtibi olacakların ileri seviyede okuryazar olması gerekmekte, ayrıca hesap-kitap işlerinden anlaması, kayıtları hatasız surette tutabilmesi gibi vasıflar aranmaktayd $1^{25}$. O esnada henüz herhangi bir eser neşretmemiş olan Eyüb Sabri'nin yazı işlerindeki mahareti ve kaleminin kuvveti keşfedilmiş olmalı ki ağırlıklı olarak kâtiplik ve eğitimle ilgili görevlere atandı.

1286'da (1869-70) Beşinci Rütbeden Mecîdî Nişanı aldı ${ }^{26}$ Bu aldığı ilk nişandır. 31 Ocak 1871 tarihinde ise ikinci bir nişana, Dördüncü Rütbeden Mecîdî Nişanı'na lâyık görüldü. Bu nişanın veriliş sebebi, Mahmûdü's-siyer adlı siyer kitabını telif etmesiydi ${ }^{27}$. 1872'de, kırk yaşına eriştiğinde Mekke'ye gitti, hac farîzasını yerine getirerek Medine'ye geçti. Kuvvetle muhtemel bir-bir buçuk sene kadar Hicaz'da kaldi ${ }^{28}$.

Sicill-i Osmânî̀ de zikredilen ve buna istinâden literatürde sorgulanmaksızın tekrarlanagelen, Eyüb Sabri'nin Hicaz bölgesinde uzunca bir müddet vazife yaptığı kaydına ihtiyatla yaklaşmak gerekir ${ }^{29}$. Zira o, hem Mekke hem de Medine'de 1289'da (1872-73)

20 Eyüb Sabri Paşa, Mir'ât-ı Mekke, I, s. 293-296.

21 DTA, YKL.d, 3972/21, 1 Ağustos 1271 (13 Ağustos 1855).

22 Bu alaylar hakkında geniş bilgi için bkz. Burcu Kurt, "Osmanlı Donanmasında Modern Teknolojiyi Yakalamak: Bahriye Sanayi Alayları”, Uludă̆ Üniversitesi Fen-Edebiyat Fakültesi Sosyal Bilimler Dergisi, XVII/28 $(2015 / 1)$, s. 79-111.

23 DTA, YKL.d, 3972/21, 15 Haziran 1276 (27 Haziran 1860).

24 DTA, YKL.d, 3972/21, 1 Temmuz 1282 (13 Temmuz 1866).

25 Kadir Türker Geçer, "XIX. Yüzyılda Osmanlı Ordusunda Rütbe Terfi Uygulamaları ve 1870 Tarihli Terfi'-i Rütbe Nizâmnâmesi”, Askerî Tarih Araştırmaları Dergisi, X/19 (2012), s. 10.

26 Fidan, a.g.e., s. 76.

27 BOA, İ.DH, 626/43575, 9 Zilkade 1287 (31 Ocak 1871).

28 Can, "Giriş", s. 54.

29 Hicaz'da uzun süre vazife yaptığını ifade eden literatür için bkz. Mehmed Süreyyâ, "a.g.m.”, s. 451; Koçu, "Eyyub Sabri Paşa”, s. 5446; Özcan, "Eyüp Sabri Paşa”, XII, s. 8; Fidan, a.g.e., s. 41; Işı, "Eyüb Sabri Paşa”, IV, s. 1368. 
bulunduğunu ve aynı yıl haccettiğini birkaç yerde vurgulamaktadır ${ }^{30}$. Bu vurgular, onun bölgeye varış ve kalış tarihi olarak 1289'u işaret etmektedir. Nitekim 1287'de (1870-71) basılan Mahmûdü's-siyer'de rastlanmayan "hacı" lâkabının da ilk defa 1289'dan sonra neşrettiği eserlerde geçtiği görülmektedir. Bunlara ilaveten 1289'dan sonraki vazifelerinin İstanbul'da olduğu dikkate alındığında, Eyüb Sabri'nin takribî bir-bir buçuk yıl kadar Hicaz'da kalmış olması daha isabetli bir görüş olsa gerektir ${ }^{31}$.

Onun Hicaz'a neden gittiği de kesin olarak aydınlatılabilmiş değildir; gidiş amacına dair elimizde bir bilgi bulunmamakta, resmî kayıtlardan da o bölgede bir görev yaptığına rastlanmamaktadır. Eserlerinde herhangi bir vazifeden bahsetmeyen Eyüb Sabri ise Mir'ât- $\iota$ Mekke'de "sâye-i şâhânede tarîk-ı hidâyet-karîn-i Haremeyn" olduğunu söyler. Bir süredir planladığı Mir' âtü'l-Haremeyn projesini hayata geçirmek üzere izin alıp hacca gitmiş olmalıdır; çünkü o, bu projeyi tamamlayabilmesinin "mutlakā Hicâz arâzī-i mes 'ûdesini seyr u seyâhate merhûn u mütevakkıf olduğundan” yani saha araştırması gerektirdiğinden bahsetmektedir ${ }^{32}$.

Hicaz dönüşünde alay eminliğine ${ }^{33}$ terfi ettirilen (25 Haziran 1874) Eyüb Sabri, eşzamanlı olarak başkâtiplik ve Mekteb-i Bahriye'de münşeat, yani metin inşası hocalığı yaptı ${ }^{34}$. İki sene sonra ise binbaşılığa terfi etti (5 Haziran 1876) ve Mekteb-i Bahriye'nin idâdî kısmına talebe yetiştirmek gayesiyle Kasımpaşa'da 1875 'te kurulan ve bir yıl sonra faaliyete başlayan Mekteb-i Rüşdiye-i Bahriye'nin müdürlüğünü üstlendi ${ }^{35}$. Mektebin en uzun süre görev yapan müdürlerinden olan Eyüb Sabri en az sekiz sene bu görevi devam ettirdi. Bu esnada, önce kaymakamlığa (yarbay) (13 Ağustos 1881) $)^{36}$; iki yıl sonra ise miralaylığa terfi etti (2 Temmuz 1883) ${ }^{37}$.

Müdürlüğünün ilk yıllarında mektebin kuruluş amacının gereğini tam olarak gerçekleştiremediği anlaşılmaktadır. Zira Mekteb-i Bahriye-i Şahane’ye yılda en az kırk

30 Eyüb Sabri Paşa, Mir'ât-ı Mekke, I, s. 232, 498, 499; Eyüb Sabri, Mir'âtü'l-Haremeyn: Mir'ât-l Medîne (Kostantiniye: Bahriye Matbaas1, 1304/1886), s. 48, 52, 53, 210 (Eyüb Sabri, Mir'ât-ı Medîne).

31 Can, "Giriş", s. 54-55.

32 Eyüb Sabri Paşa, Mir'ât-ı Mekke, I, s. 192-193. Daha önceki çalışmamızda vazife icabı gönderilmiş olmasını "muhtemel” bulmuştuk. Ancak mevcut bilgileri yeniden yorumladığımızda bu görüşü tashih etmek gerekti (Can, "Giriş", s. 66).

33 Askerî kâtip sınıfına ait bir vazifeli olup yüzbaşı ile binbaşı arasında yer alan alay eminleri, mensup oldukları alayın idarî ve hesap işleriyle meşgul olurlardı (Mehmet Zeki Pakalın, Osmanlı Tarih Deyimleri ve Terimleri Sözlüğü, I, Milli Eğitim Basımevi, İstanbul 1993, “Alay Emini”, s. 45).

34 DTA, YKL.d, 3972/21, 13 Haziran 1290 (25 Haziran 1874); BOA, İ.DH, 686/47848, 10 Cemâziyelevvel 1291 (25 Haziran 1874).

35 DTA, YKL.d, 3972/21, 24 Mayıs 1292 (5 Haziran 1876); BOA, İ.DH, 724/50509, 23 Cemâziyelevvel 1293 (16 Haziran 1876). Bu mektebe dair bkz. Mehmet Korkmaz, "Osmanlı Askerî Eğitiminde Modernleşme Çabaları: Kasımpaşa Bahriye Askerî Rüşdiye Mektebi”, Tarih Dergisi - Turkish Journal of History, sayı 72 (Aralık 2020), s. 115-137.

36 DTA, YKL.d, 3972/21, 1 Ağustos 1297 (13 Ağustos 1881); BOA, Y.MRZ.d, nr. 77, 24 Temmuz 1297 (5 Ağustos 1881).

37 DTA, YKL.d, 3972/21, 20 Haziran 1299 (2 Temmuz 1883); BOA, İ.DH, 888/70690, 29 Şaban 1300 (5 Temmuz 1883). 
öğrenci göndermesi beklenirken bu sayı 15-25 seviyesinde kalmışt ${ }^{38}$. Eyüb Sabri Bey’e göre bunun sebebi Mekteb-i Rüşdiye'nin yeterli öğrenci bulamamasıydı. Kasımpaşa'da bir ibtidai mektep yoktu ve mevcut sıbyan mekteplerinin rüşdiyeye altyapı oluşturacak bir eğitim programı uygulamamaları, öğrenci bulunmasını zorlaştırıyordu. $\mathrm{Bu}$ durumun bir süre daha devam etmesinin rüşdiye sınıflarını tamamen öğrencisiz kalma tehlikesiyle karşı karşıya bırakabileceği uyarısında bulunan Eyüb Sabri, oldukça düşük maliyetli bir çözüm önerisi sundu: Buna göre Mekteb-i Rüşdiye-i Bahriye'nin içine iki kısımdan oluşan bir sınıf açılmalıydı. Açılacak ilk sınıfta bir yıl boyunca ibtidai mektebinin müfredatı okutulmalı, sınıfını geçenler rüşdiyeye kayıt hakkı kazanmalıydı. Açılacak diğer sınıfta ise Mekteb-i Bahriye-i Şahane'nin idâdi kısmının birinci sınıf müfredatı okutulmalı, bu derslerden başarılı olanlar mezun edilerek doğrudan yüksek mektebe alınabilmeliydi. Eyüb Sabri’nin bu teklifi Bahriye Nezareti tarafından da uygun görüldü̈ ${ }^{39}$.

Eyüb Sabri Bey sadece mektep müdürlüğü yapmıyor, aynı anda bazı komisyonlarda da faal olarak görev alıyordu. 1884 senesinde, Islahat-1 Bahriye Komisyonu'ndaki görevlerinin yoğunluğundan ötürü mektepte sürekli bulunamadığını gerekçe göstererek bir müdür muavini kadrosu ihdas edilmesini talep etti. O yıl mektebin toplamda 300'den fazla öğrencisi vardı. Bahriye Nezareti bu talebi uygun bularak Eyüb Sabri'nin tavsiye ettiği Fethiye kalyonunda görevli Binbaşı Ahmed Fahri Bey’i müdür muavini olarak atad $1^{40}$. Bu tarihten itibaren komisyon işlerine yoğunlaştı̆̆ı ve mektep işlerini muavini kanalıyla yürüttüğü anlaşılmaktadır.

31 Ocak 1885 'te mirlivalığa terfi ettirilerek “paşa” unvanı alan Eyüb Sabri'nin ${ }^{41}$ hocalık ve müdürlük gibi vazifeleri dışında görev aldığı komisyonlardan ilki 1880-83 yılları arasında üyesi olduğu Bahriye Eytam Sandıkları Tedkikat Komisyonu'dur ${ }^{42}$. Bir diğeri ise Bahriye'deki 1slahat ve sair birçok faaliyetin daha etkili, koordineli ve tek elden yürütülebilmesi maksadıyla teşkil edilen Islahat-1 Bahriye Komisyonu'dur ${ }^{43}$. Paşa, 1886 yılına kadar bu komisyonun ikinci başkanlığını üstlenmiş, vefatına kadar ise komisyon reisi olarak vazife yapmıştır ${ }^{44}$.

38 DTA, MKT, 396/75, 23 Zilkade 1300 (25 Eylül 1883). Mektebin ilk yıllarından itibaren bu sıkıntının devam ettiği anlaş1lyyor; zira mektep 1879 senesinde de sadece 25 mezun verebilmişti (Tercümân-ı Hakîkat (Mekâtib-i rüşdiye şâkirdânı içün haftada bir kere neşr olunur) [Küçük Tercümân-ı Hakîkat], nr. 1 (28 Eylül 1879), s. 1.)

39 Korkmaz, a.g.m., s. 124.

40 Korkmaz, a.g.m., s. 125.

41 BOA, İ.DH, 938/74321, 18 Rebiülâhir 1302 (4 Şubat 1885).

42 Fidan, a.g.e., s. 54-56.

43 Bu komisyonun ismi birkaç kez değişikliğe uğramıştır. Mesela, 1286 (1869-70) ve 1293 ’te (1876-66) Islahat ve Kavânîn-i Bahriye ismiyle anılırken 1883 y1lında ismi Bahriye Islâhât ve Tedkîk-i Muhâsebât Komisyonu olarak değiştirilmiştir. Sâlnâme-i Bahrî: Sene 1307, s. 41; Gencer, a.g.e., s. 329; Nurcan Bal, İstanbul Deniz Müzesi Osmanlıca Bahriye Mühür ve Damga Koleksiyonu, I, Deniz Kuvvetleri Komutanlığı, Ankara 2008, s. $159,167$.

44 DTA, YKL.d, 3972/21; Fidan, a.g.e., s. 57-62. Salnâmede komisyon reisi olarak Bahriye nazırı, vekili olarak da Eyüb Sabri Paşa'nın ismi geçmekle beraber Paşa'nın bilfiil komisyon reisliği yaptığı, DTA'daki ilam ve mazbata suretlerinden açıça görülmektedir (Sâlnâme-i Bahrî: Sene 1307, s. 41; DTA, BH.ISLH.KOM.d, 29/93, 29 Ağustos 1304/10 Eylül 1888; BH.ISLH.KOM.d, 14/107, 27 Kânunisani 1301/8 Şubat 1886). 
Bahse konu komisyon; Mekteb-i Bahriye ve Mekteb-i Rüşdiye-i Bahriye'deki derslerin düzenlenmesi, araç-gereç temini, subaylar için yabancı dil kursları açılması ve kâtiplere ilave muhasebe dersleri verilmesi gibi bilumum eğitim meselelerinin yanı sıra kitap basımı, askerlerin iaşesinin tanzimi, gemilerin erzak alışveriş izinlerinin düzenlenmesi, tersane hastahanesinin ve işçilerinin sorunlarının giderilmesi, gemi ve tersanelerin muhasebelerinin kontrolü, liman reisliklerinin teftişi ve yolsuzlukla mücadele gibi Bahriye'yle alâkalı çok geniş bir yelpazede çalışmalar yürütmekte, kararlar almaktaydi ${ }^{45}$.

Paşa bu komisyonun bir âzâsıyken 1888 'de Bahriye Nezâreti'nin talebi üzerine Dördüncü Rütbeden Osmânî Nişanı ${ }^{46}$ ve 1889 y1lında da İkinci Rütbeden Mecîdî Nişanı ile taltif edildi ${ }^{47}$. Bu iki nişanın veriliş sebebine dair herhangi bir bilgiye ulaşılamamıştır. Bununla birlikte, veriliş tarihlerine bakıldığında, Osmânî nişanının, Bahriye Nazırı Hasan Hüsnü Paşa'nın (1832-1903) Bahriye Sıbyan Taburları'ndaki çocuk ve gençlerin temel dinî bilgileri öğretmek maksadıyla Eyüb Sabri Paşa'ya sipariş ettiği Esbâbü'l-inâye fî tercemeti Bidâyeti'n-nihâye'nin basılması, Mecîdî nişanının ise Mir'âtü'l-Haremeyn'in baskısının tamamlanması vesilesiyle verildiği söylenebilir.

Eyüb Sabri Paşa, Mir'âtü'l-Haremeyn'in son cildinin neşri üzerinden henüz iki sene geçmişken muhtemelen Medeniyyet-i Arabiyye isimli bir Arapça tarih kitabının tercümesiyle uğraşıyordu. Bu sırada ne olduğu zikredilmeyen bir hastalıkla boğuştuğundan "nâ-mizâc" bir hâlde idi. 30 Eylül 1890 tarihinde pazartesiyi salıya bağlayan gece saat üç sularında (alaturka saat ile onu yirmi beş geçe) henüz elli sekiz yaşındayken vefat etti ${ }^{48}$. Naaşı, Kasımpaşa Kulaksız Kabristanı'na, üveysî yolla müntesip olduğu Bayramiye'nin Melâmiye kolu meşayıhından İdris-i Muhtefî’nin (ö. 1615) ayakucuna defnedildi ${ }^{49}$.

\section{Entelektüel Yönü, Muhiti ve Eserleri}

Muallim ve müverrih vecheleriyle dikkat çeken Eyüb Sabri Paşa aynı zamanda eli kalem tutar, dil bilir bir bahriyelidir. Eserleri incelendiğinde şairâne ve selis bir üsluba, aynı zamanda araştırmacı ve müdakkik bir yapıya sahip olduğunu görmek mümkündür. Kariyeri boyunca, ağırlıklı olarak eğitim ve öğretime dair vazifelerde bulunmuş ${ }^{50}$, ayrıca Haremeyn

45 Mesela bkz. DTA, BH.ISLH.KOM.d, 12/114, 17 Nisan 1301 (29 Nisan 1885); 12/37, 13 Temmuz 1301 (25 Temmuz 1885); 3/16, 18 Şubat 1300 (2 Mart 1885); 14/107, 27 Kânunisani 1301 (8 Şubat 1886); 14/108, 30 Kânunisani 1301 (11 Şubat 1886).

46 BOA, İ.DH, 1096/85925, 20 Zilhicce 1305 (28 Ağustos 1888).

47 Fidan, a.g.e., s. 77.

48 BOA, Y.PRK.ASK, 65/59, 15 Safer 1308 (30 Eylül 1890).

49 Mehmed Tahir, "Eyüb Sabri Paşa”, III, s. 959; Er, a.g.e., s. 586; Can, "Giriş", s. 56-57. Medfun bulunduğu mahal, kırmızı demir parmaklıklarla çevrili ve etrafına nazaran yüksekçe bir mevkidedir. Mezartaşı kitâbesi, mezarın konum ve krokileri için bkz. Can, "Ekler”, II, s. 1416-1420.

50 Öyle ki dönemin Bahriye Nazırı Hasan Hüsnü Paşa, Sultan’a yazdığı bir arîzada onun bu yönünü öne çıkarır: "Şu yolda ihtiyâr eylediği gayret ve fedâkârîden ve husûsıyle kendisi Tersâne-i Âmire'nin cihât-ı ilmiyye ve askeriyyesince me'mûr olduğu hıdemât-ı mühimmede dahi fevka'l-âde ibrâz-ı âsâr-ı reviyyet ü sadâkat etmekde[dir]”' (BOA, Y.PRK.ASK, 17/29, 29 Cemâziyelevvel 1300/7 Nisan 1883). 
tarihi ve edebiyatına kayda değer mesai hasretmiştir. Böylece elli sekiz yıllık hayatı boyunca binlerce sayfa hacminde altısı telif, ikisi tercüme toplam sekiz eser vermiş ve çeşitli konularda makaleler neşretmiştir ${ }^{51}$. Onun bu entelektüel kabiliyeti, araştırmacı kişiliğinin yanı sıra içinde bulunduğu seçkin kültürel muhitle açıklanabilir. Dolayısıyla gazeteci, şair, âlim, şeyh ve devlet adamı gibi devrin birçok önemli şahsiyetinin yer aldığg bu zengin entelektüel çevreye değinmek gerekir.

\section{a. İçinde Bulunduğu Kültür İklimi}

Eyüb Sabri Paşa'nın entelektüel çevresinin hayli zengin ve seçkin olduğu söylenebilir. Yalnızca eserlerine takriz yazanlara bakıldığında bile -ki sadece Mir'âtü'l-Haremeyn'e otuz iki takriz yazılmıştır- bu nitelikli çeşitliliği görmek mümkündür. Öyle ki bu muhitte, Ahmed Midhat Efendi'den Ahmed Cevdet Paşa'ya, Yenikapı Mevlevîhanesi şeyhi Osman Selahaddin Efendi'den Muallim Nâci'ye, Osmanlı'daki popüler bilim dergilerinin öncüsü Mecmûa-i Fünûn'un çıkmasını sağlayan Münif Mehmed Paşa'dan Şeyh Muhammed Zâfir ve Ebülhüdâ'ya kadar pek çok meşrep ve meslekten insan vardır.

Devrinin ileri gelen şahsiyetlerinden mürekkep bu kültür iklimi, Eyüb Sabri Paşa'nın entelektüel üretimini ve kendini adadığı eğitim misyonundaki tercihlerini şekillendirmiştir. Gerek mektepteki görevleri gerekse ortaya koyduğu eserleri, ahlâklı ve iyi eğitim almış fertler yetiştirmeyi kendisine misyon edindiğini gösterir. $\mathrm{O}$, vefatına dek yazmaktan geri durmamış, tarih kitapları dışında kendisini eğitime adayarak çocuk ve gençlere yönelik nasihatnâme türünde gazete yazıları ve eserler kaleme almıştır.

Bu yönleriyle onun Tanzimat aydını Ahmed Midhat Efendi’yle (1844-1912) benzeştiği söylenebilir. Zira Ahmed Midhat'a "gazetecilerin pîri” ve "kırk beygir gücünde yazı makinesi" "52 gibi sıfatların takılma sebebi, halka okuma alışkanlığı aşılamak ve toplumun eğitim seviyesini yükseltmek üzere gazete, kitap vs. çıkarmak için gecesini gündüzüne katmasından başka bir şey değildir. Ahmed Midhat'ın gazete ve romanlarıyla yapmaya çalıştığını, Eyüb Sabri mektep hocalığı ve müdürlüğüne ilaveten gazete yazıları ve kitaplarla yapmaya çalışmıştır. Her ikisi de sade ve anlaşılabilir bir üslupla yazmak konusunda benzer kayg1lara sahiptir.

Paşa'nın, endişe ve emelleri benzeşen Ahmed Midhat ile sıkı bir ilişkisi olduğu söylenebilir. Zira eserlerini bastırmadan önce çoğunlukla Ahmed Midhat'in Tercümân-ı

51 Ayrıca sehven Paşa'ya atfedilen kimi eserler de vardır. Bunlar Vak'a-i Ashâb-ı Fîl ve Esbâb-ı Mu cizesi, Şehnâme tercümesi, Menâkıb-ı Sultân Süleymân (Risâle-i Pâdişâhnâme veyâ Kânûnînnin Savaşlarının Manzûm Târîhçesi), Necâtü'l-mü'minîn, Ahvâl-i Cezîretü'l-Arab ve İzhârü'l-Hakk'tır. Müellif yahut eser adı benzerliklerinin, bu eserlerin Paşa'ya atfedilmesinde önemli rol oynadığı anlaşılmaktadır (Konuyla ilgili etraflı bilgi için bkz. Fidan, a.g.e., s. 84-88).

52 Şevket Rado, "Ahmet Mithat Efendi”, İdeal Gazeteci, Efendi Babamız Ahmet Mithat, haz. Münir Süleyman Çapanoğlu, Gazeteciler Cemiyeti Yayınları, İstanbul 1964, s. 173. 
Hakîkat'inde tefrika eden Paşa, rüşdiye talebeleri için yayınlanan Küçük Tercümân-ı Hakikat'in 26 sayısından 23'üne de yazılar yazmıştır. Öte yandan eserlerinin reklamları aynı gazetede yayınlandı̆̆ı gibi bazen Ahmed Midhat, Paşa'nın eserlerine dair hususî yazılar kaleme almış ${ }^{53}$, ayrıca Mir'ât'a da bir takriz yazmıştır.

Döneminin ilim, kültür ve edebiyat muhiti içerisinde önemli bir yer edindiği anlaşılan Paşa'nın eserlerinin ve bu muhitin bazı terfilerinde etkisi olduğu ve nizamnâme esaslarına göre asgarî süreyi beklemesi gerekirken daha öncesinde yükseldiği görülmektedir. İki y1l içinde miralay, bir buçuk yılda da mirliva oluşu bu cümleden olarak zikredilebilir ${ }^{54}$. Bahriye Nazırı Hasan Hüsnü Paşa'nın talebiyle gerçekleşen bu tür terfilerde Mir'âtü'l-Haremeyn yahut Mescid-i Nebevî ve Mescid-i Haram maketleri gibi eserlerinin de etkili olduğu söylenebilir ${ }^{55}$.

\section{b. Kitapları ${ }^{56}$}

Eyüb Sabri Paşa'nın eserleri genelde, bir şekilde ya Hz. Peygamber'in hayatına yahut Hicaz tarih ve edebiyatına taalluk eder. Mesela onun ilk telifi olan Mahmûdü's-siyer, kronolojik kurguyla kaleme alınmış bir siyer kitabıdır. Mekteb-i Bahriye talebelerinin istifade etmesi maksadıyla telif ettiğini belirttiği ikinci eseri Azîzü'l-Âsâr Şerh-i Kasîde-i Bânet Sü 'âd ise meşhur Kasîde-i Bürde'nin bir şerhidir. Paşa Hicaz'dayken, Mir'âtü'l-Haremeyn için yaptığı araştırma ve çalışmalar esnasında elde ettiği bilgileri, bazı kitaplardan istifade ederek genişletmiş ve Tekmiletü'l-menâsik ismiyle müstakil bir menâsik kitabı telif etmiştir. Yine bu türde bir eseri, İmam Tirmizî’nin (ö. 892) Hz. Peygamber'in iç ve diş güzelliklerini ele aldığg meşhur Şemâ'ilü'n-nebeviyye'sinin Türkçe çevirisi olan Tercümetü'ş-şemâ 'il' dir ${ }^{57}$.

Paşa'nın Hicaz tarihine dair iki önemli eseri ise Târîh-i Vehhâbiyân ve Mir'âtü'lHaremeyn'dir. Vehhâbilerin tarihine dair kalem oynatan ilk kişilerden olan Eyüb Sabri, Vehhâbîlerin itikatta atası olarak vasıflandırıldığı Karmatîlerle başladığı, ardından Vehhâbîlerin ortaya çıkışı, itikatları, bölgedeki işgal ve faaliyetleri gibi konuları ele aldığı Târîh-i Vehhâbiyân'ı yazabilmek için Hicaz ihtiyarlarıyla görüşerek adeta bir sözlü tarih çalışması yapmıştır.

Eyüb Sabri Paşa'nın araştırma ve çalışmayla geçen ilim hayatının esas semeresi, Mir'âtü'l-Haremeyn' dir $^{58}$. Ömrünün on altı senesini hasrettiği bu Hicaz külliyatı, Türkçe

53 Mir'ât-ı Medîne'nin tamamlanmasını kutlayarak müelliften sitayişle bahsettiği yazısı bu cümledendir (Ahmed Midhat, “Mir'ât-ı Medîne'nin Hitâmı”, Tercümân-ı Hakîkat, nr. 2933 (14 Mart 1888), s. 1).

54 Geçer, “a.g.m.”, s. 9; BOA, İ.DH, 938/74321, 18 Rebiülâhir 1302 (4 Şubat 1885).

55 DTA, YKL.d, 3972/21, 19 Kânunisani 1300 (31 Ocak 1885); BOA, Y.MTV, 16/79, 23 Rebiülevvel 1302 (10 Ocak 1885); C.BH, 256/11863, 14 Rebiülâhir 1302 (31 Ocak 1885).

56 Eyüb Sabri’nin kitapları hakkında ayrıntılı bilgi için bkz. Can, "Giriş”, s. 57-64.

57 Eser, günümüz harflerine aktarılmıştır (İmam Tirmizî, Tercümetü’ş-Şemâil, çev. Eyüp Sabri Paşa, haz. Reyhan Çorak - Fakirullah Y1ldız - Mehmet Asağ, Ketebe, İstanbul 2021).

58 Mir'âtü'l-Haremeyn'in ayrıntılı bir incelemesi için bkz. Can, “Giriş”, s. 66-113. 
kaleme alınmış en kapsamlı Haremeyn tarihi olma vasfını hâlen muhafaza etmektedir. Hicaz'da yaptığ 1 saha araştırmalarını pek çok kaynak eserdeki bilgilerle harmanlayan Paşa, Mir'ât-ı Mekke, Mir'ât-ı Medîne ve Mir'ât-ı Cezîretü'l-Arab adlarını taşıan, beş büyük ciltte toplanmış üç kitaptan mürekkep “Mir'âtü'l-Haremeyn”i vücuda getirmiştir. Eserdeki kaynak çeşitliliği ve bunların tenkid süzgecinden geçirilerek kullanılmasının yanı sıra tematik anlatım tarzının benimsenmesi, müellifini döneminin önde gelen tarihçileri arasında anılmasına zemin hazırlamıştır. Esasen bir tarih kitabı olmakla birlikte bu eser, bazen bir menâzil ve menâsik kitabı gibi hacca gideceklere tavsiyeler ve pratik bilgiler verir; bazense bir hâtırat ve seyahatnâme tadı verir. Bir yandan okuyucusunu tarihî bilgilerle donatırken, öte taraftan 1slahat lâyihası gibi devlet ricaline tasarruf tedbirleri sunar ${ }^{59}$.

Eyüb Sabri'nin Hicaz'la ilgili olmayan diğer iki eserinin ise ahlâkî yönü ağır basan çalışmalar olduğu söylenebilir. Bunlardan Riyâzu'l-mûkınîn, temelde İmam Gazzâlî’nin (ö. 1111) İhyâ'u ulûmi'd-dîn'inin ibadet bahsinden istifadeyle hazırlamış olup ağırlıklı olarak ahlâkî, bir nebze de fikhî ve tasavvufî meselelere temas etmektedir. Son eseri Esbâbü 'l-inâye fì tercemeti Bidâyeti'n-nihâye ise yine Gazzâlî'nin Bidâyetü'l-hidâye'sinin tercümesidir. Bahriye'deki çocuk ve gençlere temel dinî bilgileri öğretmek maksadıyla hazırlanan bu kitabın ahlâk, itikat ve tasavvuf yönü baskındır ${ }^{60}$.

\section{c. Makaleleri}

Eyüb Sabri Paşa'nın yukarıda kısaca bahsedilen telif ve tercümelerinin yanı sıra gazetelerde yayınlanmış -şimdiye kadar tespit edilebilen- birtakım yazıları ile Medeniyyet- $i$ Arabiyye isimli bir tercüme projesi mevcuttur ${ }^{61}$. Paşa, kaleme aldığı makalelerini, Tercümân-ı Hakîkat ile rüşdiye talebeleri için çıarılan Küçük Tercümân-ı Hakîkat adlı haftalık gazetede neşretmiştir.

\section{i. “Ayn-ı Zübeyde” Başlıklı Yazı Dizisi}

Mekke'nin önemli su kaynaklarından Ayn-1 Zübeyde'nin tamir edilip temizlenmesi için teşkil edilen komisyona Hint müslümanlarının cömert bağışlarda bulunduğunu öğrenen Eyüb Sabri, bahsi geçen su kaynağının tarihi ve önemine dair uzun bir yazı kaleme alarak Tercümân-ı Hakîkat'e gönderir ${ }^{62}$. Gazetenin 17-25 Haziran 1880 tarihli sayılarında neşredilen

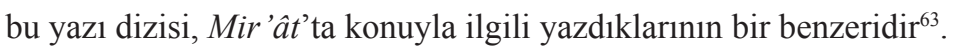

59 Bu eserin ilk iki cildinin Türkçede ilk ilmî neşri 2018 senesinde yapılmıştır (Eyüb Sabri Paşa, Mir'âtü'lHaremeyn (Haremeyn Tarihi): Mir'ât-ı Mekke (İnceleme-Metin), I-II, haz. Ömer Faruk Can - F. Zehra Can, ed. Göker İnan, Türkiye Yazma Eserler Kurumu Başkanlığı, İstanbul 2018).

$60 \mathrm{Bu}$ eser 2021'de günümüz harflerine aktarılarak neşredilmiştir (İmam Gazzâlî, Nihayetin Başlangıcı: Bidâyetü'l-Hidâye Tercümesi (Esbâbu'l-'Inâye fi Tercemeti Bidâyeti'n-Nihâye), çev. Eyüp Sabri Paşa, haz. Mehmet Asağ, Büyüyen Ay, İstanbul 2021).

61 Etraflı bilgi için bkz. Can, "Giriş", s. 65.

62 Eyüb Sabri, “Ayn-1 Zübeyde”, Tercümân-ı Hakîkat, nr. 604 (17 Haziran 1880), s. 3.

63 Eyüb Sabri Paşa, Mir'ât-ı Mekke, II, s. 896-921; Fidan, a.g.e., s. 136-137. 


\section{ii. “Nasîhatü'l-etfâl” Başlıklı Yazı Dizisi}

$\mathrm{Bu}$ yazı dizisi, rüşdiye talebelerine okuma alışkanlığı kazandırmak, ahlâkî ve zihnî gelişimlerine katkı sağlamak amacıyla 1296' da (1879) bir grup rüşdiye müdür ve mualliminin teşvikiyle yayın hayatına başlayan "Tercümân-ı Hakîkat (Mekâtib-i rüşdiye şâkirdânı içün haftada bir kere neşr olunur) "64 adlı haftalık gazetede neşredilmiştir. Öğüt verici yönü öne çıkan bu yazı dizisi, küçük boy çıktığı için "Küçük Tercümân-ı Hakîkat” adıyla iştihar etmiş olan bu gazetenin 2'nci sayısından 24'üncü sayısına kadar fasılasız 23 sayı boyunca yayınlanmıştır. İyi huy sahibi ve ahlâklı olmanın faziletleri ile başlayan dizide, genelde her bir sayıda doğruluk, teslimiyet, dua, meşveret, hayâ, tevekkül, saadet, şükür, akıl, tevazu, ticaret, çok uyumanın zararları ve gadr gibi müstakil bir konu ele alınmıştır. Eyüb Sabri, Mekteb-i Bahriye-i Rüşdiye'nin müdürlüğünü yapmaktayken bu yazı dizisini kaleme almış, ele aldığı konuları ise çoğunlukla İslâm tarihine dair çeşitli hikâye ve kıssalarla bezemiş ve öğrencilerin iyi bir ahlâkla yetişmeleri amacını gütmüştür ${ }^{65}$.

\section{iii. İttihad-ı İslâm'ın Bir Aracı Olarak Cuma Hutbesinin Bazı Kısımlarının Türkçeye Çevrilmesini Teklif Ettiği Bir Yazısı}

Eyüb Sabri'nin bu yazısı, Türkçe hutbe tartışmalarının tarihine katkı sunabilecek mahiyettedir ${ }^{66}$. Tercümân-ı Hakîkat' in 707'nci sayısında (19 Ekim 1880) yayınlanan iki sütun uzunluğundaki yazıyı, Bayezid Camii’nde kıldığı cuma namazında tesadüf ettiği Medineli bir imam vesilesiyle kaleme almıştır. Paşa, makalesinde, imamın lâl edecek derecede gayet müessir ve beliğ bir hutbe irad ettiğini, fakat hutbe Arapça olduğundan bu dili anlamayan cemaat arasında beklenen etkiyi oluşturmadığını söyler.

Ona göre hutbenin mühim bir kısmını, insanların istifade etmesi için verilen öğüt ve nasihatler oluşturur; dolayısıyla bunların lâyıkıyla anlaşılması gereklidir. Öyle ki hutbenin muhtevası ne ise buna Türkçesinin de ilave edilmesi, Müslümanlar arasında görülmekte olan nifak ve ayrılık emarelerinin ortadan kaldırılmasında pek çok fayda sağlayacaktır. Paşa iddiasını daha da ileri götürerek, bunu İttihâd-1 İslâm'a hizmet edecek şeylerin en mühimi olarak vurgular. Ona göre bu öğüt kısımlarına Türkçesinin eklenmesinin iki büyük faydası daha vardır: (1) Ayet ve hadislerin anlamını öğrenen insanlar bununla amel edebilirler. (2) Hutbeyi dinleyebilmek için daha çok insan camiye gelecek, böylece namaz kılanların sayısı artacaktır.

64 Toplam 26 sayı çıkabilen gazete, hedef kitlesinin seviyesine göre düzenlenmiş dilbilgisi, imla, kitabet ve dört işlem gibi çeşitli konularla talebelere yönelik çeşitli oyunlara yer vermiş; konu ve meselelerin anlatımında hikâye ve diyaloglardan istifade edilmiştir. Bunun yanında gazetede talebeyi teşvik edici kimi sorular sorulmuş ve doğru cevaplayanlara mükâfatlar verilmiştir. Ayrıca "çalışkan ve terbiyeli" talebenin gazetede ilan edilerek teşvik edileceği, "haylaz ve terbiyesiz"lik yapanlarınsa teşhir edileceği ilk sayıda duyurulmuştur (Küçük Tercümân-ı Hakîkat, nr. 1, 1, 5, 6 vd). Bu gazete, bir yüksek lisans çalışmasına konu olmuştur (Merve Büşra Göçen, Tercüman-ı Hakikat Gazetesi'nin II. Abdülhamid Dönemi Çocuk Eğitimine Katkisl (1296-1297/18791880), Fatih Sultan Mehmet Vakıf Üniversitesi, Sosyal Bilimler Enstitüsü, Yayınlanmamış Yüksek Lisans Tezi, İstanbul 2018).

65 İlk yazı 19 Şevval 1296 (5 Ekim 1879), son yazı ise 10 Rebiülâhir 1297 (21 Mart 1880) tarihinde yayınlanmıştır.

66 Bkz. Ek 3. 
Bununla birlikte Eyüb Sabri, hutbenin sırf Türkçe irad edilmesi gibi bir anlayışa sahip olmadığını ve Arapça kısımlarının muhafaza edilmesi gerektiğini söyler. Onun teklifi, ayetlerle hadislerin Türkçeleriyle beraber okunması ve hutbede dile getirilen öğütlerin Türkçeye tercümesinden ibarettir. Bu durumu, o günün İstanbul'unda neşredilen Arapça el-Cevâ'ib ve Farsça Ahter gazetelerine benzeterek açıklamaya girişen Eyüb Sabri, bu gazetelerin en azından birer sayfalarının Türkçe olması durumunda, Türklerin de istifadesine açık olabileceğini dile getirerek yazısını sonlandırır ${ }^{67}$.

\section{d. Bir Muamma: Eyüb Sabri Paşa'nın Yaptırdığı Mescid-i Nebevî ve Mescid-i Haram Maketleri Nerede?}

Eyüb Sabri’nin eserleri sadece kitap ve gazete yazılarından müteşekkil değildir. Kaleminin kudretinin yanı sıra zevk-i selim ve hüner sahibi olan Paşa, Hicaz'dayken inceleme imkânı bulduğu Mescid-i Haram ile Mescid-i Nebevî’nin maketlerini yaptırıp Bahriye Nazırı Hasan Hüsnü Paşa vasıtasıyla Sultan II. Abdülhamid'e takdim etmiştir. Esasında mescit maketi yapmak yeni bir icat değildi, daha önce de pek çok maket yapılmıştı ${ }^{68}$. Fakat Paşa'nın proje yürütücülüğünü üstlendiği maketler, belli bir oran-orantı gözetilerek dikkatli bir şekilde imal edilmişti ve muadillerinden pek çok yönüyle üstündü. Yapımında sadece gözlem ve saha araştırmasıyla yetinilmemişti. 1883 yılında tamamlanan Mescid-i Nebevî maketi, Sultan Abdülmecid devrindeki büyük restorasyon sırasında mühendislerce hazırlanan plan ve çizimlere dayanılarak imal edilmişti. Ayrıca dış görünüşü haricinde mescidin iç kısımlarına da gerekli ihtimam gösterilmiş ve Hücre-i Saadet'in içi muteber hadis kitaplarındaki bilgilere muvafik surette yapılmıştı ${ }^{69}$.

Eyüb Sabri’nin, 1/120 oranında yaptırdığını ve mescitleri birebir yansıttığını ifade ettiği bu maketlerin akıbetleri meçhuldür. $\mathrm{Bu}$ bölümde mevcut literatürdeki bilgilere ilaveten tespit ettiğimiz bazı maketlerden hareketle Paşa'nın maketlerinin izi sürülecek, nerede olabilecekleri tespit edilmeye çalışılacak ve bu esnada literatürdeki birtakım hatalı bilgilerle tutarsızlıklara işaret edilerek tashihleri yoluna gidilecektir.

Mir'âtü'l-Haremeyn'de Eyüb Sabri'nin, bu maketlerin Sultan Abdülmecid'in Hırka-i Şerif Camii'ne konulmak üzere imal ettirdiğini belirtmesi ${ }^{70}$ ve mezkûr camide gerçekten bir Mescid-i Nebevî maketinin bulunması bazı araştırmacıları yanıltmış, hatta buradaki maketin Eyüb Sabri’ye 1850'li yıllarda Sultan Abdülmecid tarafından ısmarlandığı ifade edilmiştir ${ }^{71}$.

67 Eyüb Sabri, "Varaka", Tercümân-ı Hakîkat, nr. 707 (19 Ekim 1880), s. 3.

68 Konuyla ilgili bkz. Gülru Necipoğlu-Kafadar, "Plans and Models in 15th- and 16th-Century Ottoman Architectural Practice”, Journal of the Society of Architectural Historians, 45/3 (Eylül 1986), s. 224-243.

69 Eyüb Sabri, Mir'ât-ı Medîne, I, s. 682; BOA, Y.PRK.ASK, 17/29, 29 Cemâziyelevvel 1300 (7 Nisan 1883).

70 Eyüb Sabri, Mir'ât-ı Medine, I, s. 682.

71 Mesela bkz. Fidan, a.g.e., s. 137-138. 
Oysa Abdülmecid, bu maketin yapılmasını Eyüb Sabri’ye emretmiş olamaz; zira 1850'lerde yirmili yaşlarda genç bir zâbit olan Eyüb Sabri, henüz hiçbir eser ortaya koymamış ve Hicaz'a ilgisi tebellür etmemiş bir delikanlıydı. Abdülmecid vefat ettiğinde bile henüz 29 yaşında bir tabur kâtibiydi. Öte yandan Abdülmecid'le bu maketlerin ilgisi, onun bânisi olduğu Hırka-i Şerif Camii'ne konulmak üzere imal ettirilmesi ve onun devrindeki imar faaliyetleri esnasında hazırlanan plan ve çizimlerin esas alınmasından ibaretti. Zaten Eyüb Sabri, Mir'ât-l Medîne'de bu yönde bir bilgi vermediği gibi konuyla ilgili arşiv belgesindeki “evvelce i'mâl eylemiş olduğu Mescidü'l-Harâm timsâl-i muhteremi huzūr-1 şevket-nüşûr-1 hazret-i zıllullâhîye takdîm kılındığı sırada Mescidü’n-Nebî timsâl-i bî-misâli dahī mîr-i mûmâ-ileyh tarafından der-dest-i i'mâl bulunduğu arz olunmuş ve timsâl-i mezkûr kemâl-i sür 'atle ikmâl etdirilerek bu kerre ref' ü arz kılınmışdır"72 ifadesi de maketlerin hem hâlihazırdaki padişaha yani Sultan Hamid'e takdim edildiğini hem de iki maketin yapılışı arasında uzun bir sürenin geçmediğini ortaya koymaktadır. Bu noktada Abdülmecid'in 1861 'de vefat ettiği, Abdülhamid'in ise bu tarihten 15 yıl sonra cülûs ettiği hatırlanmalıdır ${ }^{73}$.

O halde, Hırka-i Şerif Camii'nde bulunan Mescid-i Nebevî maketini kim yapmıştır sorusu öne çıkmaktadır. Bu maket gerek ebat gerekse çeşitli özellikleri bakımından, Mühendishane-i Berrî-i Hümayun erkânından Binbaşı Ressam Hacı İzzet Efendi'nin yaptığ $1^{74}$ maket olmalıdır. Eyüb Sabri, 1852'de İstanbul'a getirilerek camiye konan 1/53 oranındaki bu ahşap maket hakkında etraflı bilgi vermektedir:

“Gāzî Sultān Abdülmecîd Hān merhûm Mescidü’n-Nebî hey’et-i kadîmesinin timsâl-i bî-
misâlini teberrüken Hırka-i Sa'âdet Câmi`-i şerîfinde bulundurmak içün Ebniye-i Âliyye
tecdîdini irâde buyurdukları zamân mücessem bir timsâl-i muhterem i‘mâl edilmesini dahī
emr u fermân buyurmuşlar idi. Bu emr-i vâcibü’l-imtisâlin icrâ-yı iktizāsı 1267 senesi [832]
Mühendishāne-i Berrî-i Hümâyûn erkânından Binbaşı Ressam Hâcı İzzet Efendi’ye havâle
ve uhde-i iktidârına Ebniye-i Âliyye mühendisliği dahī tevcîh ve ihâle edilerek Medîne-i
münevvere cânib-i âlîsine gönderilmiş idi. İzzet Efendi, Dârü's-sekîne-i Medîne'ye vusūlünde gerek Harem-i sa'âdet'in ve gerek Hücre-i mu'attara'nın zarîh-i münevvere dîvârına varıncaya kadar her cihetini dâhilen ve hāricen gāyet dakīk sūretde mesâha edip parça parça resimler ve bu resimlerin mikyâsiyla mütenâsib kalıblar yapdıkdan sonra bir kit'a ahşâb model-i bî-bedel tasnî‘ ve i‘mâl ve [1]268 senesi Dersa'âdet'e sevk u irsâl etdi. Timsâl-i mezkûr mazhar-1 nazar-1 kabûl ve takdîr-i âlî olup sâniha-pîrâ-y1 sudûr olan irâde-i seniyye-i pâdişâhî üzerine Eski Alî Paşa Câmi'-i nûr-lâmi‘i civârında esâs-gîr-i istikrâr olan Hırka-i Sa'âdet ma‘bed-i latīfinin

72 BOA, Y.PRK.ASK, 17/29, 29 Cemâziyelevvel 1300 (7 Nisan 1883).

73 Can, "Giriş", s. 74.

74 Bir arşiv belgesinde bu maketi yapanlar "Mehmed Raif Paşa ve mühendisler" olarak belirtilmiştir. Mescid-i Nebevî'nin tamirinden sorumlu olan Raif Paşa, bu modelin yapımına ancak nezaret etmiş olsa gerektir. Paşa'nın etrafındaki mühendislerden biri olan ve Paşa'yla birlikte Medine'ye giden İzzet Efendi'nin, Eyüb Sabri'nin belirttiği gibi maketin yapımını üstlenmiş olması makul ve mümkün gözükmektedir (BOA, A.\}MKT. UM, 100/45, 7 Şaban 1268/27 Mayıs 1852). 
mü'ezzin mahfili dâ'iresine vaz' edilip câmekân mahfaza dâhiline alındı ... Zikr olunan model, harem-i melâ'ik-hıdem-i Cenâb-1 Nebevî hey'et-i kadîmesinin aynı ve mesâha-i tūlâsının elli üç cüz'ünde bir cüz’ü olup oymaları [12]67 senesi Hicâz-1 mağfiret-tırâz kit'a-i mukaddesesinde bulunmuş olan Hâfız Hâcı Alî Efendi nâmında hezârfen bir zâta oydurulduğu mervîdir. [833] Aslına kemâl-i müşâbeheti cihetle bu model-i bî-bedelin seyr ü temâşâsı mescid-i şerîf-i Medîne'yi ziyârete şebîh olacağını ashâb-1 ihlâs ve muhabbete ihtār ve tavsiye ederiz." 75

Camide sergilenen maket burada belirtildiği üzere ahşaptır ${ }^{76}$. Ayrıca Osmanlı Arşivleri’nde yer alan vesikalar da Eyüb Sabri'nin yukarıda verdiği bilgileri teyid etmektedir ${ }^{77}$. Netice olarak, Hırka-i Şerif’teki maketin İzzet Efendi'nin yaptığı maket olduğu açığa çıkar. O halde, Mir 'ât'ta geçen, Eyüb Sabri'nin maketi “Sultān Abdülmecîd Hān merhûmun Hırka-i Sa 'âdet Câmi'-i şerîfine vaz' olunmak” üzere imal ettirdiği bahsini nasıl yorumlamak gerekir? Bu maketlerin camiye konulduğu ve sonradan bir şekilde kaybolduğu bir ihtimal olarak dile getirilebilir. Diğer bir ihtimale göre ise yeni maketler Hırka-i Şerif Camii'ne hiç konulmamış olabilir. Zira Eyüb Sabri, maketlerinin camiye konulduğundan bahsetmez, yalnızca böyle bir niyetten bahsetmektedir. Bu durumda Eyüb Sabri'nin yaptırdığı maketler nerede olabilir?

Hırka-i Şerif Camii haricinde Topkapı Sarayı Kutsal Emanetler Dairesi’nde bir başka Mescid-i Nebevî maketi bulunmaktadır ${ }^{78}$. Üçüncü bir maket ise 2007 yılında Türk ve İslâm Eserleri Müzesi’nde (TİEM) düzenlenen "Bir Kul, Bir Resul" sergisinde teşhir edilmiştir" . Hemen belirtmek gerekir ki özel bir koleksiyonda yer alan ve diğer iki makete nazaran daha orantısız ve az özenli olduğu gözlemlenen bu sonuncu maketin, özellikleri itibariyle Eyüb Sabri'nin maketi olma ihtimali çok zayıftır.

Künyesinde Abdülmecid devrine ait olduğu belirtilmekle birlikte, Topkapı Sarayı'ndaki maket ise daha yakından incelenmeyi hak etmektedir. Zira öncelikle ebat olarak bu, Eyüb Sabri'nin maketi olabiliir ${ }^{80}$. İkinci olarak, arşivdeki bazı kroki ve çizimlerin bu maket ile benzeştiği görülmektedir ${ }^{81}$. Bu da Eyüb Sabri’nin, mühendislerin çizimlerine muvafik olarak maketleri yaptırdığı bilgisini teyid edebilir. Üçüncü olarak, Eyüb Sabri'nin Mir'ât- $\iota$

75 Eyüb Sabri, Mir'ât-ı Medîne, II, s. 831-833.

76 Bkz. Ek 7.

77 Ali Sar1, Medine'de Osmanlı Dini Imar Faaliyetleri: Mescid-i Nebevi Örneği (1818-1861), Marmara Üniversitesi, Türkiyat Araştırmaları Enstitüsü, Yayınlanmamış Yüksek Lisans Tezi, İstanbul 2012, s. 61, 63. Bu eserde, İzzet Efendi’nin yaptığı maketin Topkapı Sarayı'ndaki maket olduğunun belirtilmesi hatalıdır. Maketler ve İzzet Efendi'nin Hicaz'a gönderilişi hakkında bkz. BOA, İ.MVL, 206/6581, 3 Cemaziyelahir 1267 (5 Nisan 1851); İ.MVL, 242/8755, 1 Cemaziyelahir 1268 (23 Mart 1852), lef 2; Eyüb Sabri, Mir'ât-ı Medîne, II, s. 682, 831-833.

78 Bkz. Ek 4.

79 Bkz. Ek 8.

$8099 \mathrm{~cm}$ x $117 \mathrm{~cm}$ büyüklüğündeki bu maket, Eyüb Sabri’nin belirttiği 1/120 oranına göre hesaplandığında o dönemki mescidin büyüklüğüne yakın bir sonuç verir. Eski ölçü birimleri için bkz. Walther Hinz, İslâm 'da Ölçü Sistemleri, çev. Acar Sevim, Marmara Üniversitesi Yayınları, İstanbul 1990.

81 Bkz. Ek 6. 
Medîne'ye eklediği Mescid-i Nebevî resminin Topkapı Sarayı'ndaki maketle benzerliği oldukça dikkat çekicidir; Yeşil Kubbe başta olmak üzere kubbeler ve minarelerin konumlanışı, yine minarelerin yapısal özellikleri maketle örtüşmektedir ${ }^{82}$. Bütün bunlar muvacehesinde, Topkapı Sarayı'ndaki maketin Eyüb Sabri tarafından yaptırılan maket olduğu iddia edilebilir.

Burada pek bahsi geçmeyen husus ise Eyüb Sabri'nin yaptırdığı Mescid-i Haram maketinin akıbetidir. Hırka-i Şerif Camii'ne böyle bir maketin konup konmadığ 1 hususu şüphelidir ${ }^{83}$. Bununla birlikte, Topkapı Sarayı Kutsal Emanetler Dairesi'nde sergilenen bir Kâbe maketinin Eyüb Sabri'nin Mescid-i Haram maketinin bir parçası olması ihtimali de gözden irak tutulmalıdır ${ }^{84}$.

\section{Sonuç}

Bu yazıda, Haremeyn tarih ve edebiyatına yönelik eserleriyle öne çıkmakla birlikte hayatı hakkında etraflı bilgi bulunmayan Eyüb Sabri Paşa'nın biyografisi ve eserleri inceleme konusu edilmiştir. Bu bağlamda, Tanzimat aydınlarından olan Paşa'nın ailesi ve eğitiminin yanısıra bilhassa üstlendiği görevlerin mahiyeti genişçe ele alınmış ve içerisinde bulunduğu kültürel muhite temas edilerek entelektüel portresi çizilmeye çalış1lmıştır.

Eyüb Sabri'nin devlet adamı, şair, yazar, şeyh ve gazeteci gibi toplumun pek çok kesiminden oldukça seçkin ve zengin bir muhite sahip olduğu gözlemlenmiş, bu çevrenin onun edebî üretimini ve bazen de terfilerini etkilediği görülmüştür. Çok daha yakın bir münasebet içerisinde olduğu anlaşılan Ahmed Midhat Efendi örneğinden hareketle, onun Tanzimat neslinin eğitim ve telif konusundaki endişelerini taşıdığı söylenebilir. Bu cümleden olarak o, erdemli, ahlâklı ve iyi eğitim almış fertler yetiştirmeyi kendine vazife addetmiş ve yazılarında mümkün mertebe anlaşılır bir dil kullanma gayreti içerisinde olmuştur. $\mathrm{Bu}$ misyonunu ise çocuklar ve gençler için ahlâkî yönü ağır basan gazete yazıları ve telif/tercüme eserler ile muallimlik ve mektep müdürlüğü gibi görevleri aracılığıyla yapmaya çalışmıştır.

82 Bkz. Ek 5.

8321 Şubat 2020 tarihinde görüştüğüm Hırka-i Şerif Vakfı yetkililerinden Muhittin Cesur Bey, Mustafa Demiröz Bey, Sümeyra Güldal Hanım ve Hırka-i Şerif Camii’nin emektarı İsmail Keleş Bey’in ifadelerine göre mevcut Mescid-i Nebevî maketi oldukça kötü bir halde depoda bulunup tamir ettirilmiştir. Depoda başka bir maketle ise karşılaşılmamıştır. Bununla birlikte Sümeyra Hanım, mahallenin eski bir sâkininin camide bir zamanlar Kâbe maketi bulunduğu ve bunun etrafında tavaf edildiği rivayetini aktarmıştır.

84 Bkz. Ek 9. Öte yandan Gülru Necipoğlu-Kafadar, Mustafa Sâfî’nin Zübdetü't-Tevârîh'ine atıfla, Topkap1 Sarayı'nda bulunan ve örtüsü Mekke'den getirilen bir Kâbe maketinin etrafında I. Ahmed'in (1603-1617) sembolik bir tavaf gerçekleştirdiğini zikreder. Günümüzde sarayda sergilenen maketin künyesinde ise 19. yüzyıla ait olduğu belirtilmiştir. Her iki bilgi doğru olarak kabul edilirse, sarayda birden fazla maketin olduğu sonucu ortaya çıkar. Sergide tek bir maket olduğundan saray depolarında başka maketlerin olup olmadığı tedkike muhtaçtır (Necipoğlu-Kafadar, a.g.m., s. 238). Bunlar haricinde, Feth-i Bülend Serçarkçısı Debbağ Yunuslu Binbaşı Abdullah Efendi'nin imal ettiği 29 Rebiülahir 1292 (4 Haziran 1875) tarihli bir başka Kâbe maketi, İstanbul Türbeler Müze Müdürlüğü envanterinde kayıtlıdır. Bu bilgiye ulaşmamı sağlayan Türk ve İslâm Eserleri Müzesi (TİEM) Müdürü Ekrem Aytar Bey ile İstanbul Türbeler Müze Müdürü Mümin Yıldıztaş Bey'e müteşekkirim. 
Paşa'nın Cuma hutbelerinin Türkçe okunması tartışmaları tarihine katkı sunabilecek bir yazısı ilk kez bu makalede mercek altına alınmıştır. Bu yazıda, hutbelerin nasihat yönünün ağır bastığından hareketle, bazı kısımlarının Türkçe tercümelerinin de okunmasının pek çok yararının olacağı, ayrıca "İttihâd-1 İslâm” hedefinin gerçekleşmesinde bundan daha iyi bir vesile olmadığı vurgulanmıştır. Bununla birlikte onun fikhî bir içtihaddan kaçındığının ve hutbelerin tamamen Türkçeleştirilmesine taraftar olmadığının altı çizilmelidir. Bu yazı, Osmanlı son döneminde ortaya çıkan ve sonraki dönemde farklı bir evre ve gayeye bürünen Türkçe ibadet tartışmalarına öncülük etmesi noktasından ayrıca dikkat çekicidir.

Makalede son olarak Eyüb Sabri'nin yaptırıp II. Abdülhamid'e takdim ettiği Mescid-i Nebevî ve Mescid-i Haram maketlerinin akıbeti tartışılmış, hâlihazırda nerede olabilecekleri sorgulanmıştır. Mescid-i Haram maketine dair koyu bir bilinmezlik hâkim olmakla birlikte Mescid-i Nebevî maketi hakkında çeşitli çıkarımlar yapmak mümkün olmuştur. Öncelikle bu maketin Hırka-i Şerif Camii'nde bulunduğu yönünde mevcut literatürdeki bilginin doğru olamayacağına işaret edilmiş ve Topkapı Sarayı'nda sergilenen maketin Eyüb Sabri'nin yaptırdığı maket olabileceği çeşitli karinelerle açıklanmaya çalışılmıştır.

\footnotetext{
Hakem Değerlendirmesi: Dış bağımsız.

Çıkar Çatışması: Yazar çıkar çatışması bildirmemiştir.

Finansal Destek: Yazar bu çalışma için finansal destek almadığını beyan etmiştir.

Teşekkür: Yazıyı okuyup birtakım önemli noktalara ve kaynaklara dikkatimi çeken Dr. Mehmet Korkmaz ile Dr. Göker İnan’a müteşekkirim.
}

Peer-review: Externally peer-reviewed.

Conflict of Interest: The author has no conflict of interest to declare.

Grant Support: The author declared that this study has received no financial support.

Acknowledgement: I'd like to express my gratitude to Dr. Mehmet Korkmaz and Dr. Göker İnan for reading the article and pointing out some key points and resources.

\section{Kaynakça/References}

\section{Arşiv Kaynakları}

Cumhurbaşkanı̆̆ğı Devlet Arşivleri, Başkanık Osmanlı Arşivi (BOA)

Cevdet Bahriye (C.BH)

İrâde Dâhiliye (İ.DH)

İrâde Meclis-i Vâlâ (İ.MVL)

Plan, Proje ve Krokiler (PLK.p)

Yıldız Maruzât Defterleri (Y.MRZ.d)

Yıldız Mütenevvi Mârûzât (Y.MTV)

Yıldız Perâkende Askerî Mârûzât (Y.PRK.ASK) 


\section{Deniz Tarihi Arşivi (DTA)}

Bahriye Nezâret-i Celîlesi Yoklama Kalemi Defteri (YKL.d)

Bahriye Islahat Komisyonu Defterleri (BH.ISLH.KOM.d)

Bahriye Nezareti Mektubi Kalemi Defterleri (MKT)

\section{İstanbul Üniversitesi Nadir Eserler Kütüphanesi (İÜ.NEK)}

Yıldız Fotoğraf Arşivi

\section{Salnâmeler ve Süreli Yayınlar}

Ahmed Midhat, “Mir'ât-ı Medîne'nin Hitâmı”, Tercümân-ı Hakîkat, nr. 2933 (14 Mart 1888).

Eyüb Sabri, “Ayn-1 Zübeyde”, Tercümân-ı Hakîkat, nr. 604 (17 Haziran 1880).

Eyüb Sabri, "Varaka”, Tercümân-ı Hakîkat, nr. 707 (19 Ekim 1880).

Sâlnâme-i Askerî: Sene 1283, Mekteb-i Harbiye-i Şâhâne, İstanbul 1283/1866.

Sâlnâme-i Bahrî: Sene 1307, Bahriye Nezâreti Fen Komisyonu, İstanbul 1307/1890.

Sâlnâme-i Bahrî: Sene 1308, Bahriye Nezâreti Fen Komisyonu, İstanbul 1308/1891.

Tercümân-ı Hakîkat, nr. 331-421 (25 Temmuz 1879-10 Kasım 1879).

Tercümân-ı Hakîkat, nr. 446 (19 Aralık 1879).

Tercümân-ı Hakîkat (Mekâtib-i rüşdiye şâkirdânı içün haftada bir kere neşr olunur) [Küçük Tercümân-ı Hakikat], nr. 1-26 (28 Eylül 1879-7 Mart 1880).

\section{Diğer Yayınlar ve Araştırmalar}

Akyıldız, Ali, "İnsanı Yazmak: 19. Yüzyıl Osmanlı Biyografi Yazıcılığı ve Problemleri Üzerine Bir Değerlendirme”, Osmanlı Araştırmaları, sayı 50 (Ekim 2017), s. 219-242.

Babinger, Franz, Osmanlı Tarih Yazarları ve Eserleri, çev. Coşkun Üçok, Kültür ve Turizm Bakanlığı, Ankara 1992.

Bal, Nurcan, Istanbul Deniz Müzesi Osmanlıca Bahriye Mühür ve Damga Koleksiyonu, I-II, Deniz Kuvvetleri Komutanlığ1, Ankara 2008.

Bursalı Mehmed Tahir, "Eyüb Sabri Paşa”, Osmanlı Müellifleri, III, haz. M. A. Yekta Saraç, ed. Mustafa Çiçekler, TÜBA, Ankara 2016.

Çağlar, Burhan, “1878-1879 Zeytun Ermeni İsyanları ve İngiliz Said Paşa’nın Aldı̆̆ı Tedbirler”, Ermeni Araştırmaları, sayı 46 (2013), s. 163-198.

Düzcü, Levent, "Osmanlı’nın Endüstri Devrimine İlk Adımları: Küçük ve Büyük Vapur", Kadim, sayı 2 (Ekim 2021), s. 113-128.

Er, Şaban, Melâmîlik ve Osmânlı Devri Melâmîleri (Hâl tercümeleri, Silsileleri, İtikâdlarl, Meşrebleri, Eserleri, Eserlerinden seçmeler, Tıpkıbasımlar, Arşiv vesikaları, Fotoğraflar), Kutupyıldızı Yayınları, İstanbul 2015.

Eyüb Sabri, Azîzü'l-Âsâr Şerh-i Kasîde-i Bânet Sü 'âd, Şeyh Yahyâ Efendi Matbaası, İstanbul 1291/1874.

Eyüb Sabri, Mir'âtü'l-Haremeyn: Mir'ât-ı Cezîretü'l-Arab, Bahriye Matbaası, Kostantiniye 1306/1888.

Eyüb Sabri, Mir'âtü'l-Haremeyn: Mir'ât-ı Medîne, I-II, Bahriye Matbaası, Kostantiniye 1304/1886. 
Eyüb Sabri Paşa, Mir'âtü 'l-Haremeyn (Haremeyn Tarihi): Mir'ât-l Mekke (İnceleme-Metin), I-II, haz. Ömer Faruk Can - F. Zehra Can, Türkiye Yazma Eserler Kurumu Başkanlığı, İstanbul 2018.

Fidan, Mehmet Akif, Eyüp Sabri Paşa ve Tarihçiliği, Türk Tarih Kurumu Yayınları, Ankara 2011.

Geçer, Kadir Türker, "XIX. Yüzyılda Osmanlı Ordusunda Rütbe Terfi Uygulamaları ve 1870 Tarihli Terfi'-i Rütbe Nizâmnâmesi”, Askerî Tarih Araştırmaları Dergisi, X/19 (2012), s. 1-42.

Gencer, Ali İhsan, Bahriye'de Yapılan Islahat Hareketleri ve Bahriye Nezareti'nin Kuruluşu (1789-1867), Türk Tarih Kurumu Yayınları, Ankara 2001.

Göçen, Merve Büşra, Tercüman-ı Hakikat Gazetesi'nin II. Abdülhamid Dönemi Çocuk Eğitimine Katkısı (1296-1297/1879-1880), Fatih Sultan Mehmet Vakıf Üniversitesi, Sosyal Bilimler Enstitüsü, Yayınlanmamış Yüksek Lisans Tezi, İstanbul 2018.

Hinz, Walther, İslâm'da Ölçü Sistemleri, çev. Acar Sevim, Marmara Üniversitesi Yayınları, İstanbul 1990.

Işık, İhsan, "Eyüb Sabri Paşa", Resimli ve Metin Örnekli Türkiye Edebiyatçllar ve Kültür Adamları Ansiklopedisi, IV, Elvan Yayınları, Ankara 2006, s. 1368.

İdeal Gazeteci, Efendi Babamız Ahmet Mithat, haz. Münir Süleyman Çapanoğlu, Gazeteciler Cemiyeti Yayınları, İstanbul 1964.

İbrahim Alaettin, "Eyüp Sabri Paşa”, Meşhur Adamlar: Hayatları - Eserleri, II, nşr. Sedat Simavi, İstanbul 1933-1935, s. 446.

İmam Gazzâlî, Nihayetin Başlangıcı: Bidâyetü'l-Hidâye Tercümesi (Esbâbu'l- 'Inâye fì Tercemeti Bidâyeti'nNihâye), çev. Eyüp Sabri Paşa, haz. Mehmet Asağ, Büyüyen Ay, İstanbul 2021.

İmam Tirmizî, Tercümetü 'ş-Şemâil, çev. Eyüp Sabri Paşa, haz. Reyhan Çorak - Fakirullah Yıldız - Mehmet Asağ, Ketebe, İstanbul 2021.

Kehhâle, Ömer Rızâ, "Eyyûb Sabrî”, Mu'cemü'l-Mü'ellifinn: Terâcimü Musannifi'l-Kütübi'l-Arabiyye, III, Beyrut 1957, s. 30.

Koçu, Reşad Ekrem, "Eyyub Sabri Paşa”, İstanbul Ansiklopedisi, X, Koçu Yayınları, İstanbul 1971, s. 5446.

Korkmaz, Mehmet, "Osmanlı Askerî Eğitiminde Modernleşme Çabaları: Kasımpaşa Bahriye Askerî Rüşdiye Mektebi” Tarih Dergisi - Turkish Journal of History, say1 72 (2020), s. 115-137.

Kurt, Burcu, "Osmanlı Donanmasında Modern Teknolojiyi Yakalamak: Bahriye Sanayi Alayları", Uludağ Üniversitesi Fen-Edebiyat Fakültesi Sosyal Bilimler Dergisi, XVII/28 (2015/1), s. 79-111.

Lewis, Bernard, “Ayyûb Sabrî Pasha”, The Encyclopedia of Islam (New Edition), I, E. J. Brill - Luzac \& Co., Leiden - London 1960, s. 796.

Mehmed Süreyyâ, "Eyyûb Sabrî Paşa", Sicill-i Osmânî yâhûd Tezkire-i Meşâhîr-i Osmâniyye, I, Matbaa-i Âmire, İstanbul 1308/1890, s. 451.

Necipoğlu-Kafadar, Gülru, "Plans and Models in 15th- and 16th-Century Ottoman Architectural Practice", Journal of the Society of Architectural Historians, 45/3 (Eylül 1986), s. 224-243.

Özcan, Azmi, “Eyüp Sabri Paşa”, DİA, XII, İstanbul 1995, s. 8-9.

Özcan, Azmi, "Eyüp Sabri Paşa”, Yaşamları ve Yapıtlarıyla Osmanlılar Ansiklopedisi, I, Yapı Kredi Yayınları, İstanbul 1999, s. 429.

Pakalın, Mehmet Zeki, Osmanlı Tarih Deyimleri ve Terimleri Sözlüğ̈̈, I, Milli Eğitim Basımevi, İstanbul 1993.

Panzac, Daniel, Osmanlı Donanması (1572-1923), çev. Ahmet Maden - Sertaç Canpolat, Türkiye İş Bankası Kültür Yayınları, İstanbul 2018.

Safvet, Bahriyemiz Târîhinden Filasalar, Matbaa-i Bahriye, [İstanbul] 1329/1911. 
Sarı, Ali, Medine'de Osmanll Dini Imar Faaliyetleri: Mescid-i Nebevi Örneği (1818-1861), Marmara Üniversitesi, Türkiyat Araştırmaları Enstitüsü, Yayınlanmamış Yüksek Lisans Tezi, İstanbul 2012.

Sayac1, Kenan, Deniz Harp Okulu Tarihçesi, Ankara 2000.

Türk Kadınları Kültür Derneği (TÜRKKAD), “Bir Kul, Bir Resul Sergisi”, Erişim: 13 Temmuz 2021, https:// turkkad.org/hizmet/bir-kul-bir-resul-sergisi 


\section{Ekler}

Ek 1: "Bahriye mirlivalarından Eyüb Sabri kulları" (IÜ.NEK, Yıldız Fotoğraf Arşivi, 90850/92, 1885).

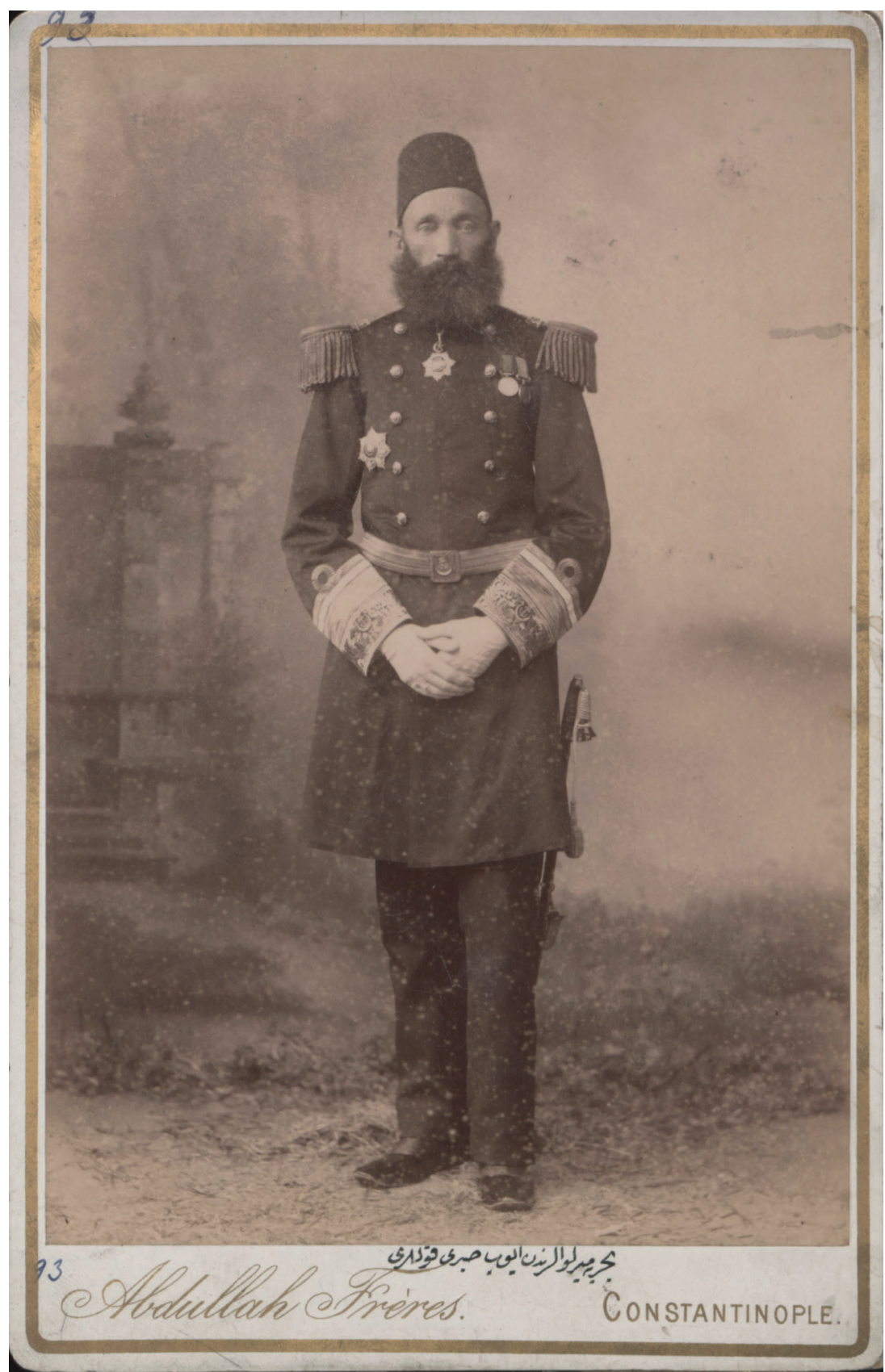


Ek 2: Eyüb Sabri Paşa'nın imzası (BOA, Y.PRK.ASK, 37/17, 4 Rebîülâhir 1304/31 Aralık 1886).

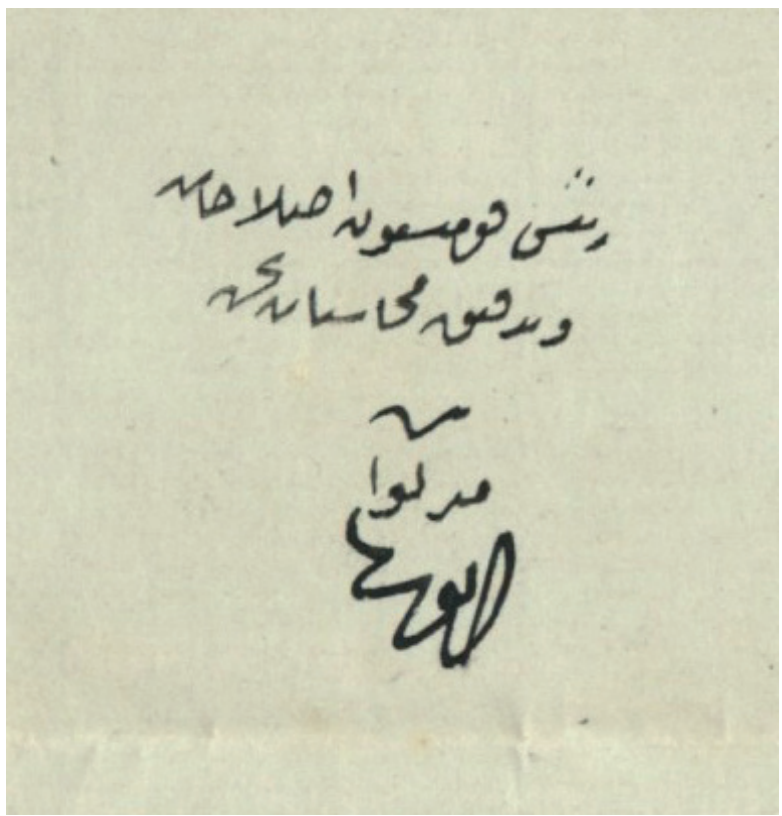


Ek 3: Eyüb Sabri'nin Cuma hutbesine dair yazdığg makale ("Varaka", Tercümân-ı Hakîkat, nr. 707 (19 Ekim 1880), s. 3).

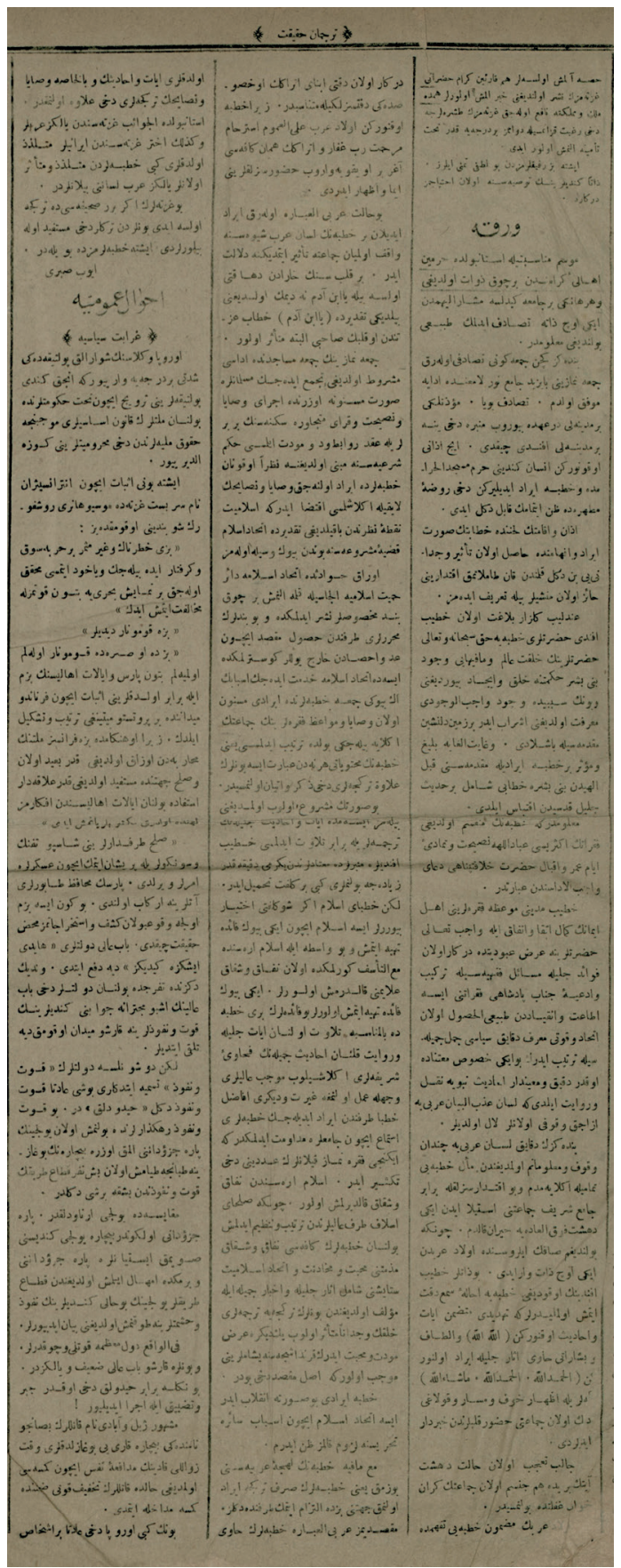


Ek 4: Topkap1 Sarayı'nda bulunan Mescid-i Nebevî maketi (C Ömer Faruk CAN, 2020).

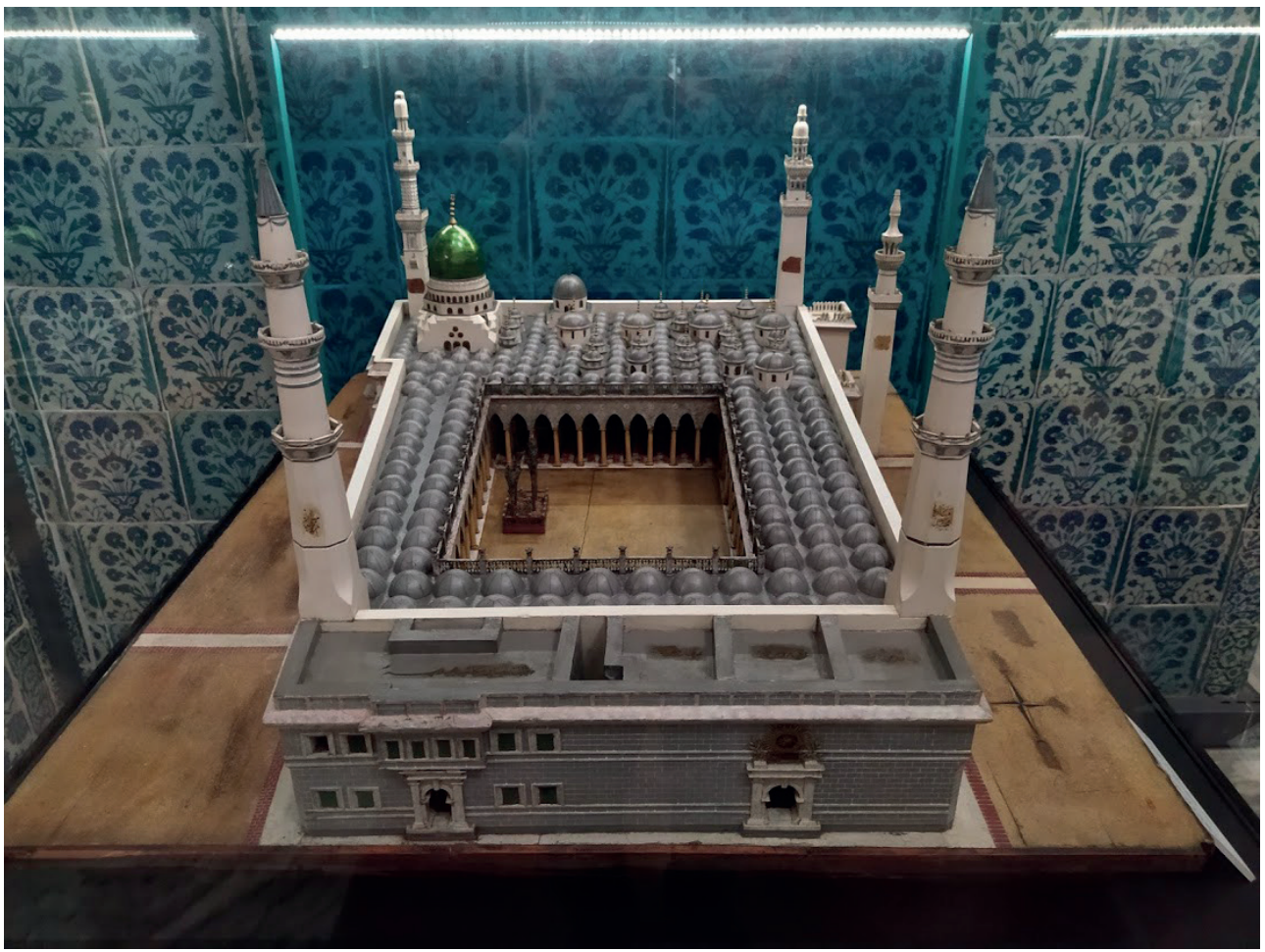


Ek 5: Bâb-1 Mecîdî içinden Mescid-i Nebevî (Eyüb Sabri, Mir'ât-ı Medîne, I, s. 8).

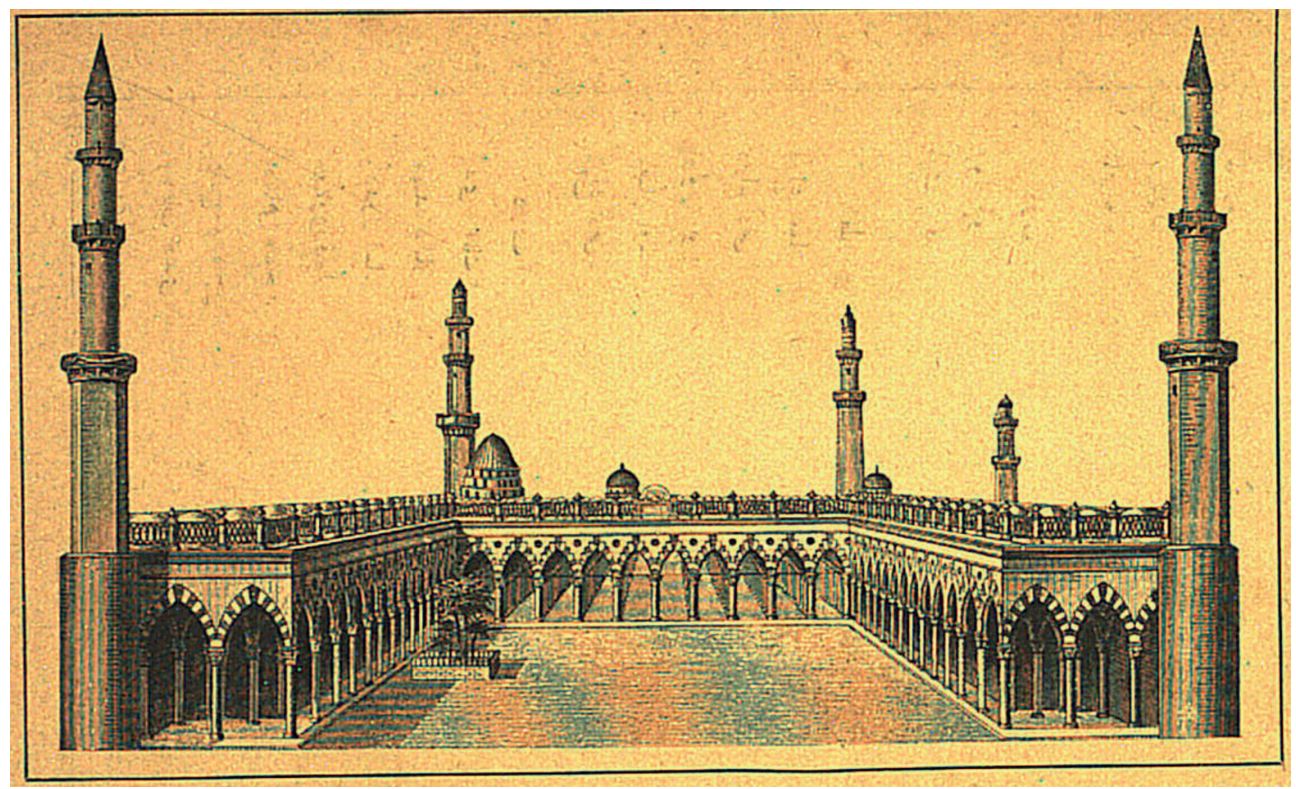


Ek 6: Mescid-i Nebevî tamir planı (BOA, Plan, Proje ve Krokiler (PLK.p), 1342, 14 Receb 1275/17 Şubat 1859).

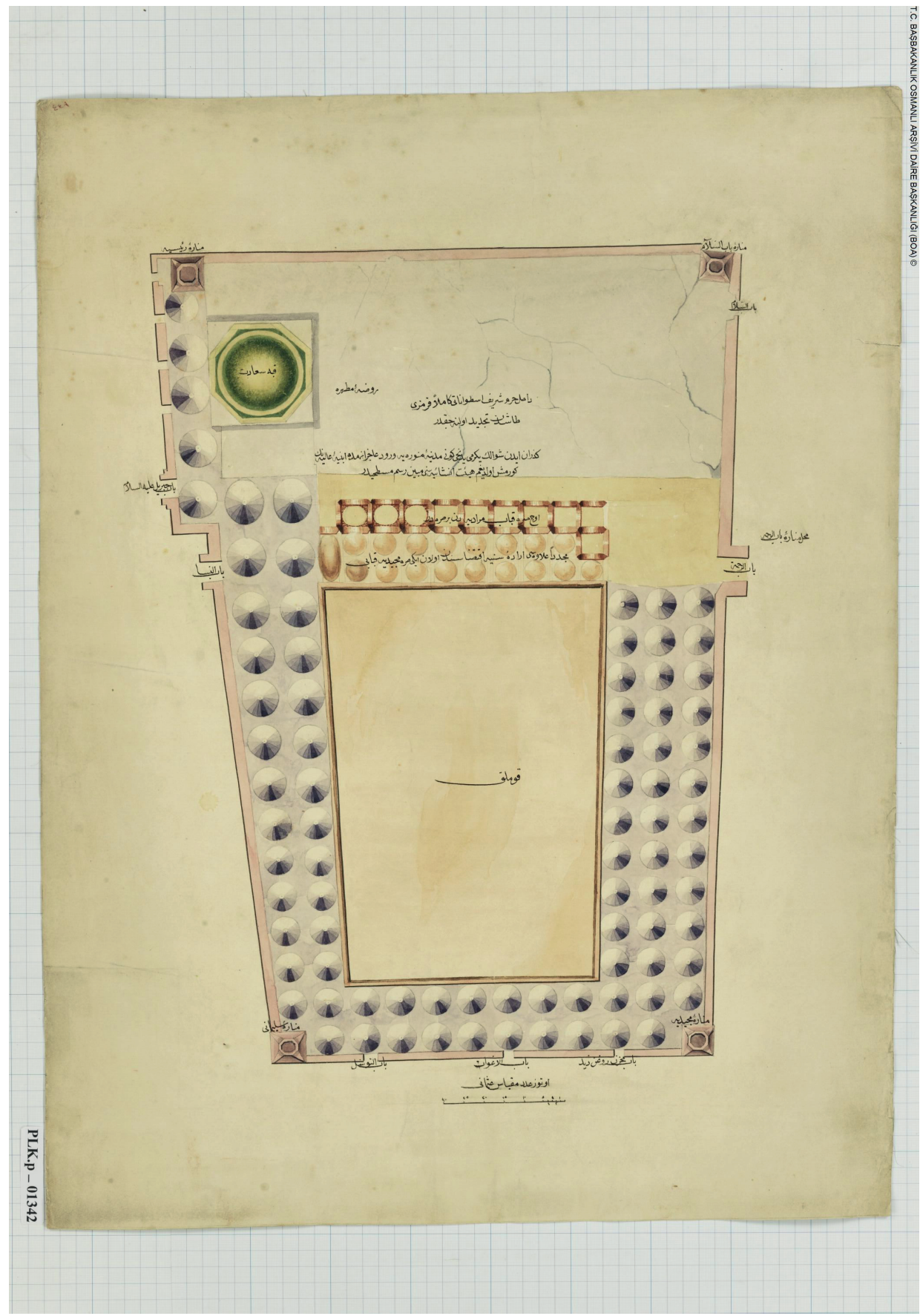


Ek 7: Hırka-i Şerif Camii'nde bulunan Mescid-i Nebevî maketi (C Ömer Faruk CAN, 2020).

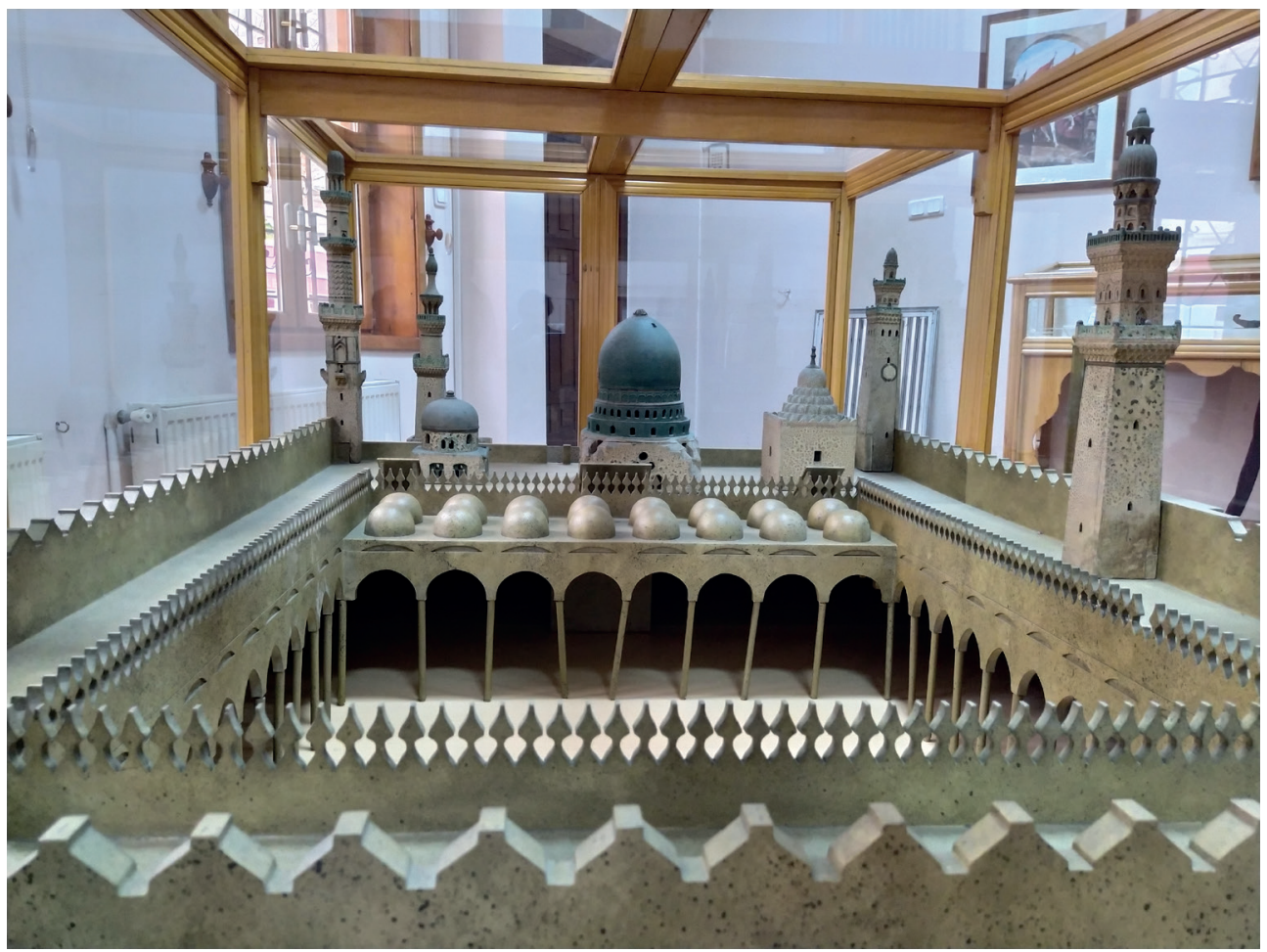


Ek 8: "Bir Kul, Bir Resul" sergisindeki Mescid-i Nebevî maketi (Türk Kadınları Kültür Derneği (TÜRKKAD), "Bir Kul, Bir Resul Sergisi”, (Erişim 13 Temmuz 2021)).

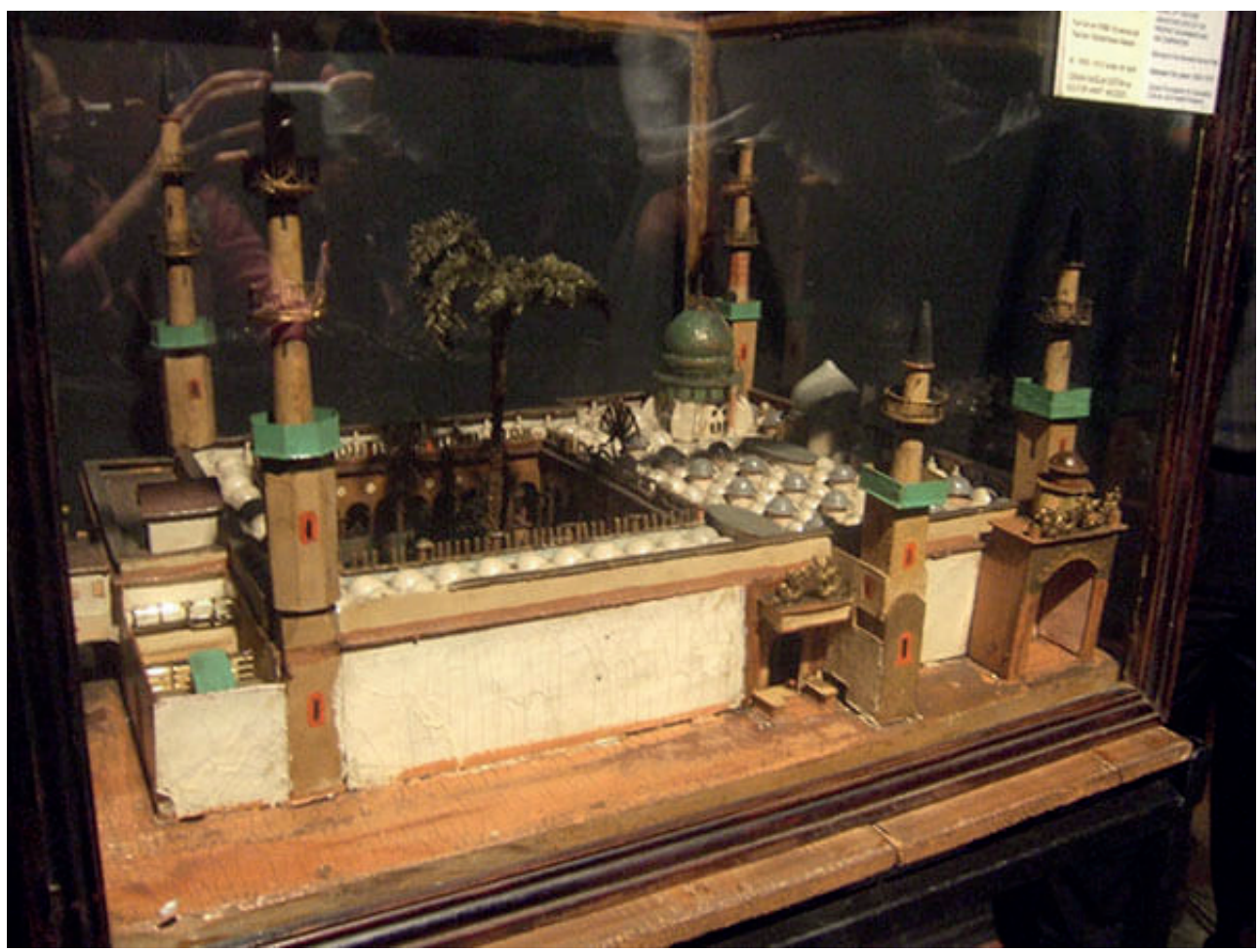


Ek 9: Topkapı Sarayı'nda bulunan Kâbe maketi (C) Ömer Faruk CAN, 2020).

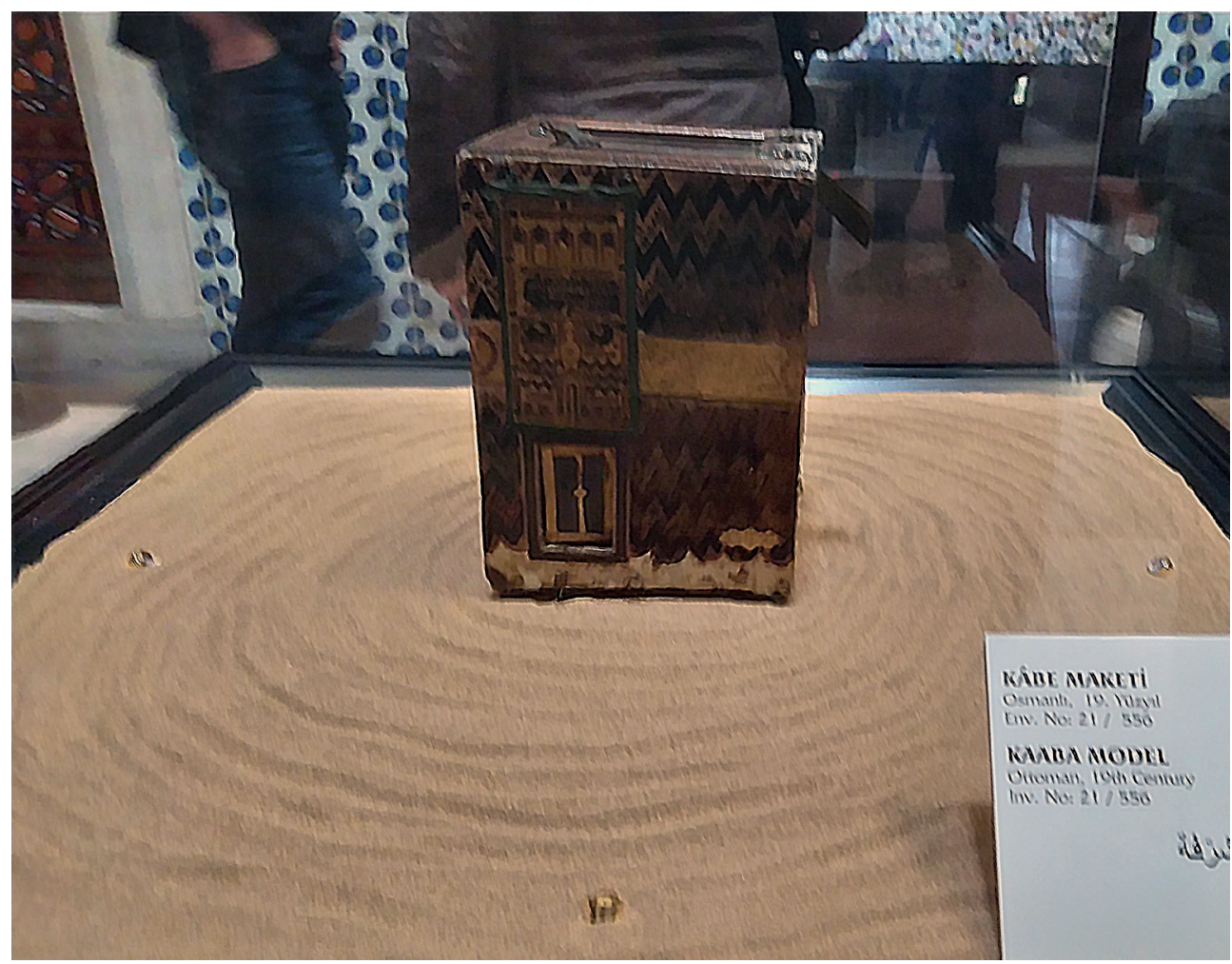


